\title{
3o. Namdar Rahmi Karatay'ın “Geçti Bor'un Pazarı”nda yer alan hiciv şiirleri üzerine bazı tahlil ve tespitler
}

\section{Kazım ÇANDIR 1}

\begin{abstract}
APA: Çandır, K. (2021). Namdar Rahmi Karatay'ın “Geçti Bor'un Pazarı”nda yer alan hiciv şiirleri üzerine bazı tahlil ve tespitler. RumeliDE Dil ve Edebiyat Araştırmaları Dergisi, (23), 441-472. DOI: $10.29000 /$ rumelide.949034.
\end{abstract}

\section{$\ddot{O} \mathbf{z}$}

Namdar Rahmi Karatay, Cumhuriyet döneminin önemli hiciv şairlerinden biridir. Onun hiciv şiirlerini topladı̆̆ı eseri “Geçti Bor'un Pazarı” 1952 yılında basılmış, daha sonra vefatından sonra öğrencileri tarafından ikinci baskısı, iki şiir daha ilave edilerek 1954’te yayımlanmıştır. Şiir sayısı da 27'den 29'a çıkmıştır. Yıllarca üzerinde çalışma yapılmayan şair hakkında Ali Birinci, Türk Yurdu Dergisinde 2012 yılında peş peşe iki yazı yayımlamıştır. Bu yazının açtığı ufukla şair hakkında çalışmalara başlandı. Onun şüphesiz edebi olarak en önemli eseri “Geçti Bor'un Pazarı” isimli şiir kitabıdır. Bu yazıda, kitapta bulunan 29 şiir her açıdan ele alınmış ve tahlil edilmiştir. Ayrıca şairin, hayatı, edebi kişiliği, mizacı ve eserleri hakkında da geniş bilgi verilmiştir. Şair, hiciv şiirlerinde hayatında yaşadığı hayal kırıklıklarını, arkadaşları ve yakın çevresiyle birlikte devrin iktidarından yediği darbeleri de anlatma cesaretini göstermiştir. Özellikle şiirlerin başlı̆̆ının nakarat kısmında sürekli tekrarlanması onun orijinal taraflarından biridir. Şair, kitaptaki tüm şiirlerini hece ölçüsüyle kaleme almış, en çok 14'lü hece ölçüsünü kullanmıştır. Nazım Şekli olarak destan tarzında yazdı̆̆ı "Yıllık Destan" dışındaki tüm şiirlerini muhammes, müseddes ve bu iki nazım şeklinin oluşturduğu karışık tarzda yazdığı metinler oluşturur. Onun hiciv şiirlerinin göze çarpan özelliği, metinlerde deyim, atasözü, halk deyişleri, ikilemeler ve tekrarlara fazlaca yer vermesidir. Bunların büyük bir kısmı da şiirlerin isimlerini oluşturur.

Anahtar kelimeler: Hiciv, Namdar Rahmi Karatay, Geçti Bor’un Pazarı, hece ölçüsü

\section{Namdar Rahmi Karatay's "Passed Bor's Market" Some analysis and determinations on satire poems}

\begin{abstract}
Namdar Rahmi Karatay is one of the important satirical poets of the Republic period. His work, "Passed Bor's Market", in which he collected his satirical poems, was published in 1952, and later, after his death, his second edition has published by his students in 1954, with two more poems added. The number of poems also increased from 27 to 29. About the poet, who has not been studied for years, Ali Birinci has published two consecutive articles in Türk Yurdu Magazine in 2012. With the horizon opened by this article, studies about the poet started. Undoubtedly, his most important literary work is his poetry book named "Passed Bor's Market". In this article, 29 poems in the book have been discussed and analyzed from all angles. In addition, extensive information is given about his life, literary personality, temperament and works. In his satirical poems, the poet has showed the courage to tell about the disappointments he experienced in his life and the troubles he suffered from the power of the period with his friends and close friends. Especially the repeated
\end{abstract}

Dr. Öğr. Gör., Çankırı Karatekin Üniversitesi, Rektörlük Türk Dili Bölümü (Çankırı, Türkiye), kazimcandir69@karatekin.edu.tr, ORCID ID: oooo-0003-2119-8979. [Araştırma makalesi, Makale kayıt tarihi: 01.04.2021-kabul tarihi: 20.06.2021; DOI: 10.29000/rumelide.949034]

Adres 1 Address

RumeliDE Dil ve Edebiyat Araştırmaları Dergisi $\quad$ RumeliDE Journal of Language and Literature Studies Osmanağa Mahallesi, Mürver Çiçeği Sokak, No:14/8 Osmanağa Mahallesi, Mürver Çiçeği Sokak, No:14/8

Kadıköy - İSTANBUL / TÜRKIYE 34714 Kadıköy - ISTANBUL / TURKEY 34714 e-posta: editor@rumelide.com

e-mail: editor@rumelide.com,

tel: +90 505 7958124, +90 216773 o 616 phone: +90 505 7958124, +90 2167730616 
repetition of the title of the poems in the chorus part is one of its original aspects. The poet has penned all his poems in the bookusing meter, using 14 size of fourteen syllables at most. All of his poems, except for the "Annual Epic", which he wrote in epic style as a form of verse, are muhammes, museddes and the texts he wrote in a mixed style composed of these two poetry forms. The salient feature of his satirical poems is that he has used a lot of idioms, proverbs, folk sayings, duplications and repetitions in the texts. Most of them consist of the names of the poems.

Keywords: Satire, Namdar Rahmi Karatay, Passed Bor's Market, syllable meter

\title{
Giriş
}

Hiciv dediğimiz edebî tür neredeyse insanlığın doğuşuyla birlikte vardır. İnsan var olduğu andan itibaren kendisini geliştiren ve yenileyen bir varlıktır. İnsanların kendi kusurlarını görmeyip başkalarının kusurlarını araması, hata yapanları acımasızca eleştirmesi hicvin doğmasına kapı aralayan önemli bir unsur olmuştur. Peki, hicivden nasibini alanlar kimlerdir diye cevap bekleyen bir soruya şöyle karşılık verilebilir: İnsanlar, toplumlar, devletlerin içindeki kurumlar, fikirler bu sorunun cevabı olarak görünür. "Hiciv" kelimesi Arapça'dır. Divan Edebiyatında bu isimde kullanılan tür, Halk şiirinde "taşlama", Cumhuriyet döneminde ise "yergi" olarak isimlendirilmiştir. Batı edebiyatında "hiciv" karşılığı olarak "satir" kelimesi kullanılır. Hiciv kelimesi edebî olarak çeşitli şekillerde tarif edilmiştir. Bunlardan bir kısmını burada verelim:

\begin{abstract}
"Birinin kusurunu ve ayıbını ortaya koymak" (Olgun, 1936: 44). "Belirli bir kişiye, bir olaya, bir sonuca mizahın saldırısı." (Öngören, 1983: 137). "Çoğunlukla mantıksız, garip ve saçma olana, ustallk ve mizah vasitalarını kullanarak herhangi bir 'hedef'e saldırmak." (Boynukara, 1997: 228). "Kişi, kurum veya toplumu alaylı tarzda eleştirme ve eleştiri metinlerinin oluşturduğu edebî tür." (Okay, 1998: 447). "Bir kişiyi, kurum ya da topluluğu/toplumu alay ederek eleştirmek, yermek, aşağılamak ve gülünç duruma düşürmek kastıyla yazılan, genellikle manzum metinlere verilen isim." (Karataş, 2007: 200).
\end{abstract}

Yukardaki tanımlara dikkatle baktığımızda, hicvin üç önemli unsurdan meydana geldiğini görüyoruz. Bunlar: Eleştiri, mizah, öfkeyle saldırma duygusudur. Hicvin en önemli unsuru eleştiridir. Eleştirinin hedefi, insandan başlayarak toplumların ve kurumların eksikliklerinin ortaya konmasına kadar geniştir. Fakat sırf eleştiri olarak kaleme alınan eserler hiciv türüne dâhil değildir. Alman düşünür Herder (1744-1803) hiciv ve eleştiri hakkında şöyle bir yorumda bulunur: "Benim oklarm isabet eder ve hastahğ iyileştirir, senin muzipliklerin ise yaralar, ama asla iyileştirmez.” (Aktaran: Öksüz, 2015: 15). Alman bilgin Herder:

'Eleştirinin 'düzeltme' aracıllğıyla senteze başka bir deyişle doğruya ulaşma çabasına dikkat çekerken hicvin saldırgan ve yaralayıcı amacının hedefe konan kurumu, sorunu veya kişiyi ‘yıratma’ya dönük olmasını bir farklılık olarak ortaya koyar.” (Aktaran: Öksüz, 2015: 15).

Hicvin en önemli ikinci unsuru mizahtır. Hiciv yazan kişinin asıl amacı; ele aldığı kişiyle veya konuyla alay etmek, onu gülünç duruma düşürmektir. Hicvin mizahî yanının ağır basması, toplum tarafından, yazılan eserin daha çabuk kabulünü sağlar. Çünkü mizah bir güldürü ögesidir ve tepkiyi azaltan bir yanı vardır. Hicvin üçüncü unsuru öfkeyle saldırma duygusudur. Toplumlar kendi yaşantıları içinde zaman zaman kişisel haksızlık ve adaletsizliklere düçar olurlar. İşte bütün bu haksızlık ve adaletsizlikleri dönemin şairi ele alır ve baştan sona bir hiciv metni oluşturur. Burada önemli olan duygu, öfkelenip karşı tarafa saldırıya geçmektir. Bundaki amaç da hicvettiğiniz kişiyi ya da kurumu olabildiğince değersizleştirmektir. Northrop Frye'ın (1912-1991) hiciv konusundaki görüşleri önemlidir. O, bu konuda şunları zikreder:

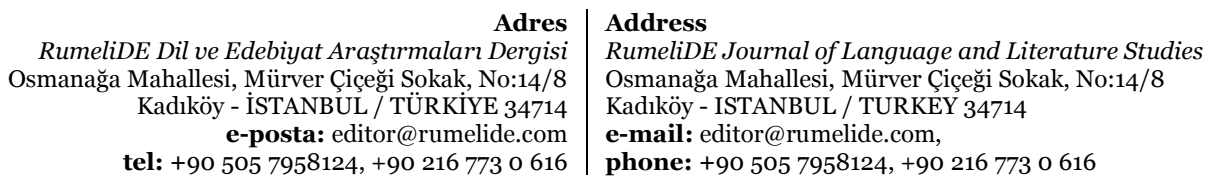


"Hiciv için iki şey zorunludur; bunlardan biri absürtlük ve garipliğin zemininde veya şairin hayal dünyasında inşa edilen ince nükteler ya da mizahtır; diğeriyse saldırılacak bir hedeftir. Mizah olmadan saldırmak ya da salt kınama hicvin bir sınırını oluşturur. Fakat bu sınır fazlasıyla bulanık ve belirsizdir de; çünkü methiyeler edebiyatın en sıkıcı ve sönük örnekleriyken hakaret ve küfür edebî sanatların en ilginç biçimidir.” (Aktaran: Öksüz, 2015: 16).

İnsanların bu tür eserleri okumasının asıl sebebi de “merak duygusu”dur. İnsan, psikolojisi gereği her an merak içinde bir yerlerden haber gelmesini bekler. Fakat yazılan hiciv türü eserlerde, bu üç unsurun aynı yoğunlukta yer almadığı görülür.

"Çevre, sanatçının karakteri, ele alınan konunun kişisel ya da sosyal nitelikte olması hicvin ağırlık yönünü değiştirir. Bazı örneklerde mizah ve alay ağır basarken öfke ve kin siliktir. Bir kısmındaysa öfke ve kin her dizede kendini hissettirirken mizah neredeyse yok derecesindedir." (Öksüz, 2015: 16).

Hiciv türüne Doğu edebiyatlarında yakın olan bir başka kavram da "hezl"dir. Eskiden beri hiciv türü eserlerin ayrımında mizah veya öfkenin ağır basması, kullanılan ölçütlerdir. Bu ölçütler sayesinde bu iki tür kesin olarak birbirinden ayrılır. Hezlin saldırması ve gülünç duruma düşürmesi açısından latife olmadığ fakat hakaret sövme seviyesine çlkmadığı için hiciv ile latife arasında bulunduğu ifade edilmiştir. (Pala, 1998: 305-306). Benzer bir ayrımın Batı edebiyatında da mevcut olduğu görülmektedir. John Dryden'in (1631-1700) "satir”in ortaya çıkışını tartıştığı önsözünden (1693) sonra Batı'da hicvin farklı örnekleri Horatius'ın mizahî ve nükteye dayalı tarzıyla Juvenalis’in temsil ettiği saldırgan ve öfke dolu üslup olmak üzere iki kutba ayrılmıştır. (Keane, 2006: 6). Mizahın ve öfkenin yoğunluğu sanatçının tercihiyle ilgiliyken hicivde değişmeyen unsur eleştirmek ihtiyacıdır. (Öksüz, 2015: 16).

Cumhuriyet Dönemi Türk Edebiyatı'nın büyük heccavlarından biri olan Namdar Rahmi Karatay'ın, "Geçti Bor’un Pazarı" adlı eserinde topladığı hiciv ve mizahî şiirleri; döneminde çok sevilmiş, takdir görmüş ve kendisine nazireler yazılmıştır. Kitabın ilk baskısı 1952 yılında yapılmış, ikinci baskısı ise 1954'te vefatından sonra öğrencileri tarafından bastırılmıştır. Bu baskıda iki metin daha ilave edilmiş şiir sayısı 29'a ulaşmıştır. Bu araştırmanın amacı, Namdar Rahmi Karatay'ın hiciv ve mizah edebiyatımıza yaptığı katkının ortaya konması ve kamuoyu tarafından pek bilinmeyen şairin edebî açıdan yerinin belirlenmesidir. Araştırmada onun, hem hayat hikâyesi hem de edebî şahsiyeti ve mizacı üzerinde dururken; diğer taraftan şairin yayımlanmış olan tek şiir kitabını içerik, şekil, dil ve üslup yönlerinden ele alacağız. Bu araştırmanın yöntemi ise esere yönelik eleştiri yöntemiyle yapılacak ve şairin yazdığı her metin ayrı ayrı değerlendirilecektir. Şairin şahsi hayatına atıfta bulunulan metinlerde, onun maruz kaldığı ya da başından geçen bir olaya göndermede bulunduğu yerlerde, dipnotlar vasıtasıyla geniş açıklamalar yapılacaktır. Sonuç bölümünde, şiirler üzerinde yapılan bulgular okuyucuyla paylaşılarak yazımız nihayete erecektir.

\section{Namdar Rahmi Karatay'ın hayatı, edebî kişiliği ve mizacı}

\subsection{Hayatı}

Namdar Rahmi Karatay, 24 Kasım 1896'da babasının evkaf müdürlüğü yaptığı Kütahya'da doğmuştur. Babası, Mehmet Rahmi Bey; annesi, Hanife hanımdır. Şairin baba tarafı Konyalı, anne tarafıysa Afyonlu'dur. İlkokul ve ortaokulu Kütahya'da okuyan Namdar Rahmi, daha sonra ailesiyle birlikte babasının memleketi olan Konya'ya gelir. Çocukluğunu geçirdiği Kütahya'dan ayrılan şair, önceleri Konya'da yaşadığı çevreye uyum sağlayamaz. Memleket ve halk farklı, şive ve konuşmalar küçük Rahmi'nin anlayabileceği türden değildir. Bu sebeple başlangıçta Kütahya'daki hayatını ve

\begin{tabular}{|c|c|}
\hline & \\
\hline aları $D$ & Studi \\
\hline $\mathrm{Mal}$ & Mahallesi, Mürver Çiçeği Sokak, No:14/8 \\
\hline Kadıköy & STANBUL / TURKEY 34714 \\
\hline $\begin{array}{r}\text { e-posta: edito } \\
\text { tel: }+905057958124,+\end{array}$ & $\begin{array}{l}\text { editor@rumelide.com, } \\
\text { +90 505 7958124, +90 } 216773 \text { o } 616\end{array}$ \\
\hline
\end{tabular}


arkadaşlarını özler. Fakat zaman geçtikçe, Konya hayatına da alışan çocuk Rahmi, yavaş yavaş yaşadığı bu çevreyi de benimser. Bunda ailesinin Konya'daki konumunun rolü büyüktür. Şair, yeni hayatını ve yaşadığı çevreyi benimsedikten sonra, çocukluk hülyalarıyla dolu ufkunu genişletmek için merakla Konya sokaklarını dolaşır.

"Küçük Namdar, artık bu coğrafyanın çocuğudur. Yaka bağlarının batısından Takkeli Dağ eteklerine kadar ki tepeler, dereler çocuk hülya ve merakıyla "Beyşehir şosesi”ne kadar dolaşıp koşuşturduğu bir alandır.” (Karatay, 1952c: 130-131, Arabacı, 1991:147).

Ayrıca şunu eklemek gerekir ki, onun çocukluğunda benliğini ve dünyasını etkileyen en önemli şahsiyet ninesidir. Şairin çocukluğunda etki alanı içerisinde kaldığı bir başka unsur ise, Kütahya’nın Çamlıca semtindeki yaşam çevresidir. Şairin dinî, içtimai, gelenek ve göreneklere dayanan mahalle çevresinden çok şey öğrendiği ve ileriki hayatında bunları bizzat kullandığını görüyoruz. Böyle bir ortam içinde yetişen Namdar Rahmi’nin, başarılı bir ortaöğretim hayatı geçirdiğine şahit oluyoruz. Bunun önemli sebeplerinden birisi de babasının, şairin eğitimiyle yakından alakadar olmasıdır.

Lise tahsilini Konya'da tamamlayan şair, Konya İdadisi’nden 1912 yılında mezun olur. Başarılı bir ortaöğretim dönemi geçiren Namdar Rahmi, daha o yıllarda kitaplarla haşır neşir olmuş ve kendisini okuma ve yazma işine adamıştır. Şüphesiz onun kitaplara düş̌ünlüğü yakın arkadaşı Naci Fikret’ten gelmektedir. Ayrıca daha lise yıllarında yazdığı makalelerin "Babalık" gazetesinin bazı sayılarında başmakale olarak yayımlanması da onu, okuma-yazma konusunda kamçılayan önemli amillerden biridir. Şairin hayatının "küçük yaşından itibaren öğrenme ve öğretme yolunda" geçtiğini ve aile çevresinin "dindar ve uhrevi bir iklim" içinde olduğunu, Ali Birinci'nin aktardığı bir metinden öğreniyoruz. (Birinci, 2012: 30). Namdar Rahmi, tahsil hayatı hakkında da şu bilgileri verir:

“İbtidaiye ve rüştiye tahsilimi mahall-i veladetim olan Kütahya'da, idadi tahsilimi vatan-ı aslimiz olan Konya'da ikmal ettim. 328'de şahadetnamemi aldıktan sonra Konya'daki Hukuk Şubesine kayd olunarak bir sene devam ettim. Ertesi sene kendi arzumla terk ederek yine Konya'da vaki olup ahiren hükûmet-i seniyece sedd edilen Fransız Mektebine girdim. Her ikisinden de tasdikname almadım. Fransızca'da yalnız kitabet ve tercümeye iktidarım vardır. Konya Darü'l-Mualliminin'den de ehliyetname aldım.” (Birinci, 2012a: 31).

Namdar Rahmi'nin 16 Kasım 1914'de başlayan meslek hayatı, 28 Ekim 1950 tarihine kadar devam etmiştir. Şair, yaklaşık olarak otuz altı sene memuriyet hayatı sürmüştür. Namdar Rahmi, mesleğe ilk girişini şöyle anlatır:

“İdadiyi burada bitirdim (1328/1912). İlkin, mektepte edebiyat hocamız olan Hayrettin Bey’in açtı̆̆ Ümit İdadisinde muallim oldum. Bir taraftan da babamın ısrarıyla Konya'daki Hukuk mektebine devam ediyordum. Mektep öğleye kadardı, öğleden sonra hocalık ettiğim mektebe gidiyordum. Hocalıktan hoşlanıyordum. Karşımda zeki, sevimli yavruları gördükçe benim de şevkim artıyor, bilmediklerimi öğreniyordum.” (Karatay, 1954: 9.)

Şair Konya, Afyon, Bursa, Ankara ve İstanbul'da çoğunluğu öğretmenlik olmak üzere memuriyet görevinde bulunmuştur. Onun görev yaptığı okullar arasında, Konya Numune Mektebi, Konya Sille Köyü Füyuzat Mektebi, Konya Erkek Lisesi, Afyon Ortaokulu, Bursa Erkek Lisesi, Ankara Gazi Terbiye Enstitüsü, İstanbul Erkek Öğretmen Okulu, İstanbul Çapa Erkek Lisesi, İstanbul Pertevniyal Lisesi vardır. Şairin en uzun süre görev yaptığı yer, 1930-1942 yılları arasında Bursa Erkek Lisesi olmuştur.

Namdar Rahmi, Dolmabahçe Sarayında, Atatürk'ün huzurunda toplanan Birinci Türk Dili Kurultayı'na Samih Rıfat'ın teklifiyle katılmış ve burada yaptığı konuşma davetliler tarafından çok beğenilmiştir. Şairin hayat hikâyesinde iki büyük kırılma vardır. Bunlardan biri, "Balarısı mecmuası"

\footnotetext{
RumeliDE Dil ve Edebiyat Araștırmaları Dergisi Osmanağa Mahallesi, Mürver Ciçeği Sokak, No:14/8 Kadıköy - İSTANBUL / TÜRKIYE 34714 e-posta: editor@rumelide.com tel: +90 505 7958124, +90 2167730616 
hadisesi, diğeri ise, İkinci Türk Dili Kurultayı'na davet edilmemesidir. "Balarısı mecmuası” arkadaşı Şekurî tarafından Konya'da çıkarılan bir dergidir. Şair, bu dergiye verdiği bir yazı yüzünden öğretmenlik mesleğinden olmuş, uzun uğraşmalardan sonra tekrar mesleğine dönebilmiştir. Birinci Türk Dili Kurultayı'ndaki başarılı konuşması ve Atatürk’ün onu takdir etmesi, dönemin bazı isimlerinde kıskançlığa yol açmış, şairin önünü kesmek için sonraki kurultaya davet edilmemiş ve unutulması sağlanmıştır.

Namdar Rahmi, 1939'da Fatma Süeda hanımla evlenmiş ve Ali Başak ve Zehra adında iki çocuğu olmuştur. Yaşadığı 57 yıllık hayatı boyunca çok sıkıntı çeken ve hayal kırıklıkları yaşayan Namdar Rahmi, hayata sıkı sıkıya bağlı bir insandır. 1942'de Gazi Terbiye Enstitüsü hocalığına atanan şair, Ankara'ya gelir. Bu görevinde birkaç yll kaldıktan sonra hastalanmaya başlar. Kendisinde "damar sertliği vardır. Çeşitli hastahanelerde tedavi görür. 1947'de İstanbul'da Çapa Kız Enstitüsüne tayin edilir.” (Muşta, 1990: 20). Hastalığı devam eden şairin,

“1948 Kasım’ında sol tarafına felç gelir. Hastalığın devamı üzerine iki yıl raporlu kalır. Fatih’teki Millet Kütüphanesinde hafif bir hizmete verilir. 1952 yılında emekliye ayrılır. 1953 yılında ailesi ile birlikte yerleşmek için gittiği İzmir'de ölür.” (Muşta, 1990: 20).

Namdar Rahmi Karatay’ın kesin ölüm tarihi, 26 Ağustos 1953’tür.

\title{
1.2. Edebî kişiliği
}

Namdar Rahmi, çok genç yaşından itibaren yazı yazmaya başlar. Yazı hayatının ilk zamanlarında dikkati çekmeyen şairin, II. Meşrutiyet döneminde önemli bir edebiyat iklimine sahip olan Konya'da iyi bir mevki kazandığı görülür. Konya'dan ayrıldıktan sonra şairin aynı verimlilikte yazı hayatını sürdüremediği, ancak kitap hâlindeki eserleriyle kamuoyunun dikkatini celp ettiğini söylememiz icap eder. Namdar Rahmi, Bursa'ya tayin edildikten sonra, orada çalışmalarını yoğunlaştırmış, 1933 yılında yazdığı "Geçti Bor’un Pazarı" adlı mizahî şiiriyle dikkatleri üzerinde toplamış; daha sonra toplumdan gördüğü bu teveccühle hiciv türünde şiirler kaleme almıştır. Şairin yazdığı bu tür şiirler, o kadar ilgi görmüştür ki bunlar kısa bir zamanda tüm yurda yayılmış ve bazı önemli görülen manzumeleri duvarlara nasihat ve ibret vermek amacıyla çerçeveli birer levha olarak asılmıştır. Yazı hayatı hakkında kendi ifadesi şöyledir:

\begin{abstract}
"Orada, daha idadide iken çıardıkları Ufk-u Ati adlı mecmuada gördüğüm "Mudhike-i nisaiyet" başlıklı yazısıyla dikkatimi çekmiş olan Naci Fikret'le arkadaş olmuştuk. Bunlar idadide bizden bir sınıf yukarıda idiler. Meğer bu genç, benim yazılarından tanıdığımdan çok derin, hudutsuz bir umman imiş. Ona olan hayranlığım gün geçtikçe artıyordu. Bu hayranlığım onun ölümüne kadar artarak sürdü. Bir de bizden bir sınıf aşağı Ali Ragıp vardı ki, şiir alanında bir harika idi, yalnız o divan edebiyatının şaheser örneklerini veriyordu. Bu iki arkadaş bana iki kanad olmuşlardı. Ben o vakte kadar Edebiyat-i cedide ile meşgul olmuştum, bilhassa Fikret'in hayranı idim ve yazılarımda hep Fikret'in tesirleri vardı. Ragıp bana divan edebiyatı zevkini tattırdı, ben de ondan geri kalmamak için gazeller, mesneviler yazıyor, ona nazireler yapıyordum. Fakat o benim için en büyük üstattı, bugün hâlâ hayranı olduğum eserleri vardır. Ayrı bir kitap hâlinde topladığım Kitaplarımın Hikâyesi adlı yazılarımda bunlardan bahsetmiştim.” (Karatay, 1954: 9-10.)
\end{abstract}

Namdar Rahmi, Konya İdadisi’nde son sınıfta öğrenciyken ilk şiirlerini o sırada daha çok öğrencilerin yazdığı "Şehab" adlı mecmuada neşretmiştir. Bu mecmua, 30 Mart 1912-4 Nisan 1913 tarihleri arasında, Konya'da 14 sayı çıkmıştır. Namdar Rahmi, sadece yazar olarak değil dergi çıkaran bir naşir olarak matbuat tarihimizde önemli bir yer edinmiştir. Onun yazı yazdığı ilk mecmua "Şehab" olmuştur. "Şehab”tan başka "Babalık, Yeni Fikir, Resimli Zaman, Balarısı, Asie Mineur, Kervan, Terbiye Postası, Selçuk, Afyonkarahisar’nnda Nur, Taşpınar, Konya, Anadolu Terbiye Mecmuası,

RumeliDE Dil ve Edebiyat Araştırmaları Dergisi Osmanağa Mahallesi, Mürver Ciçeği Sokak, No:14/8 Kadıköy - İSTANBUL / TÜRKIYE 34714 e-posta: editor@rumelide.com tel: +90 $5057958124,+902167730616$
Address

RumeliDE Journal of Language and Literature Studies

Osmanağa Mahallesi, Mürver Çiçeği Sokak, No:14/8

Kadıköy - ISTANBUL / TURKEY 34714

e-mail: editor@rumelide.com,

phone: +90 5057958124 , +90 2167730616 
Gerçek Yolu, Ar, Millî Mecmua, Uludă̆, Bursa Vilayet Gazetesi, Türk Yurdu” gibi gazete ve mecmualarda da yazı ve şiirleri neşredilmiştir. Namdar Rahmi’nin ilk şiirlerini yayımladığı "Şehab" mecmuası, onun hayatında özel bir anlam taşır. Namdar Rahmi, mahlâs olarak Şehab'ı kullanmıştır. Bu da gösteriyor ki, bu mecmuada yazmak onun için çok kıymetlidir. Şehab'ın ilk sayısında yayınlanan "Hayat Yolunda"2 başlıklı şiir, kendi imzasını taşıyan ilk şiir olması açısından dikkate değerdir. Şiirin yazılış tarihi 25 Mayıs 1327/7 Haziran 1911'dir. Namdar Rahmi, Birinci Dünya Savaşı'nın son yıllarında, Türk Ocağı Konya Şubesi adına Vali Muammer Bey’in desteğiyle çıkardığı 19 sayılık "Ocak”3 mecmuasının hemen her sayısında yazı yazmış, yazı işleri müdürlüğünü de yürütmüştür. Şairin dergilerde yayımlanan bazı şiirleri şunlardır:

“Orman”, "Sevgi ve Bahar: Anadolu Duyguları”, "Yaz Günü”, “Geçti Bor’un Pazarı”, "Hayat Pokeri”, "Karaman'ın Koyunu”, Fânilik", "Bir Hatıra”, "Bursa'da Lodos", "Cumhuriyet Gençliğine”, "Cumhuriyet Destanı", "Hayat Yolunda”, "Hazân-ı Âmâl”, "Irmak", "Kurbağalı Çeşme", "Leyle-i Vâpesin", "O Neydi Gönül”, "Teşrih-i Beşer", "Türklük ve Hilâle”, "Kurtuluş Ertesinde: Bir Anıt Bir Ant..."

Şair, aynı zamanda felsefe eğitimi almış iyi bir felsefecidir; felsefî ve edebî pek çok yazı da kaleme almıştır. Bunların künyelerini uzun uzun yazarsak makalenin sınırlarını aşmış oluruz. O yüzden bunların önemli bir kısmının sadece isimlerini verecek ve bununla yetineceğiz. Bu makale ve yazıların isimleri şunlardır:

"İlk Gençlik Terbiyesi”, "(Lisanda Tasfiye) Münasebetiyle”, "Ahlâk ve Terbiyenin Ensabiyatı”, "Aile”, "Amellerimizin Mertebeleri ve Sanat", "Antropoloji-Beşeriyât I-III", "Arzu ve Sanat", "Ataletten Mütevellid Faziletler”, "Atatürk'ün Ölümü Ne Demektir", "Besim Atalay Bey’in İtirâzına Cevaptır”, "Bir Garip Mütefekkirin Nazarında İslamiyet”, "Bir Mektuptan”, "Bir Oluş Hikâyesi”, "Biz İnsanlığın En Büyük Harikasını Gördük”, "Bizde Takdir ve Tenkid”, "Bursa Ömürbey Vakıfnamesi ve Yeni Bulunan Mühim Bir Vesika”, "Cemiyette Felsefe Eğitiminin Rolü”, "Cumhuriyet İdeolojisi”, "Cumhuriyet ve Atatürk", "Devlet ve İstatistik", "Devrim Diyalektiği I-VI”, "Elem ve Sanat", "Elem ve Şuur”, "Emil Zola", "Emperyalizm ve Enerjetizm", "Emperyalizme Nazaran İçtimaiyat", "Enerjetik Ruhiyat I-II", "Enerjetizm ve İçtimaiyat", "Enerjetizme Müstenid İçtimaiyat”, "Faziletin Manası", "Felsefî Musahabe: Garp’te Ruhiyat Cereyanları 1-2 (Tercüme)", "Fertçilik-Cemiyetçilik", "Ferdî ve İçtimaî Ruhiyat", "Finalizme Karşı Kaderiyat”, "Finalizme Karşı Kudretiyet”, "Folklor: Halk Edebiyatı Örnekleri”, "Gençlik ve İhtiyarlık 1-2", "Gençlik, İhtiyarlık, Zübbelik", "Göze Görünmeyen İnsan”, "Halk Sanat ve Edebiyatına Dair Düşünceler", "Hodgamî ve Ucb”, "Hürriyet ve Esaret 1-2", "Hüsnün Menşei ve Mahiyeti”, "İçtimaiyat Tetkikleri”, "İdealizm-Realizm", "İlimleri Tevhid Eden Umumi Mebde", "İlmin Mecra-yı Tekâmülünü Tayin Eden Âmiller I-IV", "İnfiradın Kudsiyeti”, "İnkılapçılık", "İnsan Makinesinin Mihanikiyeti", "Kadınlı Bahsi: Asrın İçtimaî Meselesi”, "Kitaplar ve Tenkitler: İffet Divanı", "Kudretiyat Noktai Nazarından Makine-İnsan", "Kudretiyat Nokta-i Nazarından Terbiye Nedir?: Yaratan Kudret, Tahrib Eden Kudret", "Kudretiyat Sistemi ve Hayatın Tarzı Telakkisi", "Kudretiyata Müstenid İçtimaiyat: Tekâmül ve Tevazûn", "Kudretiyata Müstenid İlim", "Kudretiyata Nazaran Usûl”, "Lisan Meselesi”, "Lisanların Teşekkülü”, "Mâlum ve Meçhul”, "Meyhane, Sarhoşluk (İsmail Zühtü’nün Ruhuna)", "Mizaç 1-2-3", "Mizahın Felsefesi (1)", "Muhit”, "Mutlakiyet ve Cumhuriyet”, "Muvazenesizlik ve Tekâmül 1-2", "Namık Kemal’in İdealizmi”, "Negativizm 1-2", "Nevzat B.”, “Ocak”, "Osmanlllık nedir?”, “Oyun ve İş 1-2”, "Paris Mektubu”, "Paristen MusahabelerKuyruk", "Rehberler ve Dallarda Hayatiyet", "Roman Hakkında”, "Ruhiyat: Kudretiyata Nazaran

Namdar Şehab (1912), "Hayat Yolunda”, Şehab Mecmuası, 30 Mart, (1), 6.

Adı geçen dergi, Konya'da 13 Kasım 1917-30 Mayıs 1918 arası Namdar Rahmi’nin Tahrir Müdürlüğünde yayımlanmıştır.

Adres $\mid$ Address

RumeliDE Dil ve Edebiyat Araşttrmaları Dergisi $\quad$ RumeliDE Journal of Language and Literature Studies Osmanağa Mahallesi, Mürver Çiçeği Sokak, No:14/8 Osmanağa Mahallesi, Mürver Çiçeği Sokak, No:14/8

Kadıköy - İSTANBUL / TÜRKIYE 34714 Kadıköy - ISTANBUL / TURKEY 34714 e-posta: editor@rumelide.com

e-mail: editor@rumelide.com

tel: +90 $5057958124,+90216773$ o 616 phone: +90 505 7958124, +90 216773 o 616 
Bediiyat", "Sanat ve İfade", "Sanat ve Uzlet”, "Sanat ve Esaret", "Sanat ve Gençlik", "Sanat 1-2", "Sulh", "Şakir Efendinin Vefatı Münasebetiyle", "Şiir ve Felsefe: Sanat", "Şivelerde Garabet", "Tekâmülün İzahı", "Terbiye: Enerjetizm ve İçtimaiyat”, "Türk Demokrasisinin ve Laikliğin Gelişmesi”, "Türk İmanı", "Üstad Mehmet Muhlis Bey'e 1-3", "Yeni Kitaplar", "Ziya Gökalp”, “Üsluplarda Şahsiyet”, "Diktatörlüğün Muhtelif Şekillerine Doğru", "Dimağ", "Lisan ve Ruhiyat", "İrrealizm-Realizm", "Tevhid-i Tedrisat Meselesi”, "Terbiye Salahiyeti”, "Terbiyenin Hedefi”, "Hasta Cihan", "Halkevleri Halkın Aydınlık Şuur Ocağıdır”, "Kızıl Elma’ya Dair Bir Vesika”, "Kâtib̂̂”, "Kemal Ergenekon’u Kaybettik", "Hakkı Baha Pars Fâniler Arasından Çekildi", "Çekirge Suyu Bu: Haşereleri Kıran Kuş Efsanesi”, "Hasta Adam", “Çorlu Adam”...

Yukarıda adı geçen bütün yazılar, şu gazete ve dergilerde yayımlanmıştır: "Anadolu Terbiye Mecmuası", "Yeni Fikir”, “Kervan Dergisi”, "Uludağ”, "Gerçek Yolu”, “Konya”, “Millî Mecmua”, "Türk Sözü Gazetesi”, “Ar”, “Afyonkarahisarı’nda Nur”, "Taşpınar”, “Ocak”, “Öğüt Gazetesi”, "Babalık Gazetesi" vb.

\subsection{Mizacı}

Namdar Rahmi'nin mizacının oluşumunda ve tekâmülünde pek çok kişinin etkisi vardır. Bunlardan en önemlisi şüphesiz ninesidir. Caner Arabacı, bu konu hakkında şöyle bir yorumda bulunur:

"Yurt dışında bulunduğu gurbet yıllarında hasretle anacağı bu şehrin yanında onun benliği ve çocukluk dünyasını şekillendirip etkileyenler arasında "nine"si başta gelmektedir." (Arabacı, 1991: 147).

Şairin ninesi derviş meşrep ve Nakşî tarikatına mensup bir kadındır. Nine, torununa Yunus Emre'den, Kaygusuz Abdal'dan, Erzurumlu İbrahim Hakkı'dan birçok ilahi parçaları okur, onun çocuk dimağının gelişmesine ve ilerde edebiyatla uğraşmasına vesile olacak kapıyı aralamış olur. Şair, bir eserinde ninesi hakkında şu bilgileri verir:

"Her vesile ile bize Allah’tan, Peygamber'den, evliyalardan söz açar, onların hikâyelerini, menkıbelerini anlatırdı. Hele Yunus Emre'yi bir türlü anlata anlata bitiremezdi." (Karatay, 1943 s.8).

Şairi bu yönde etkileyen yegâne amil ninesi değildir. Ona ek olarak yaşadığı çevre de mizacının oluşmasında önemli bir etkendir. Bu çevre onun ilk çocukluğunu yaşadığı Kütahya'dır. Namdar Rahmi, bu konu hakkında da yine aynı eserinde şunları zikreder:

"Bulunduğumuz şehirde pek çok tekke vardı. Hele mahallemizdeki Rufâî tekkeleri bizim her mübarek günde koştuğumuz yerlerdi. Daha o yaşta mahalle arkadaşlarımızla birlikte, başlarımıza, tekkeden iğreti verilen külahı giyerek zikir halkasına girer ve tıpkı büyük dervişler gibi biz de coşarak kendimizden geçerek höykürürdük. Böylece tekkeden çıkarken kendimizi sanki Allah'a çok yaklaşmış gibi görür ve içimizden gizli gizli böbürlenirdik.” (Karatay, 1943: s.8).

Onun mizacının oluşmasında, özellikle ilk çocukluğunu geçirdiği Kütahya’nın Çamlıca semtinin büyük önemi vardır. Ruh yapısı üzerinde derin tesirler bırakan ilk çocukluk yılları için kendisi şu ifadeleri kullanır:

"Sabahları gün doğmadan mahallemizdeki camiye giderek sabah namazı kılmak da dünyada tadılacak zevklerin en özgünlerinden biriydi. Sabahın sessiz alaca karanlığı camiye varıncaya kadar ruhlarımızı kutsal bir hava gibi yıkardı. Titrek mum ve kandil ışıkları ile yarı gölgeli camiin, sanki bu geçici dünya âleminden bambaşka bir rengi ve bir dekoru vardı. Oraya girince ruhlarımız bir Tanrı âlemine dalmış gibi olurdu. Sabah namazında kalabalık olmazdı. İmamın sesi tapınağın kalın

\begin{tabular}{r|l} 
Adres & $\begin{array}{l}\text { Address } \\
\text { RumeliDE Dil ve Edebiyat Araştırmaları Dergisi }\end{array}$ \\
RumeliDE Journal of Language and Literature Studies \\
Osmanağa Mahallesi, Mürver Çiçeği Sokak, No:14/8 & Osmanağa Mahallesi, Mürver Çiçeği Sokak, No:14/8 \\
Kadıköy - İSTANBUL / TÜRKIYE 34714 & Kadıköy - ISTANBUL / TURKEY 34714 \\
e-posta: editor@rumelide.com & $\begin{array}{l}\text { e-mail: editor@rumelide.com, } \\
\text { phone: +90 505 7958124, +90 } 216773 \text { o } 616\end{array}$ \\
tel: +90 505 7958124, +90 216 773 o 616 &
\end{tabular}


duvarlarında dünya seslerine benzemeyen bir (öte) ye sürükler, götürürdü. Dönüşümüzde ninemizi seccadesi üzerinde binlik tesbihini çekmeye dalmış bulurduk. İşte böyle bir çevre içinde bizim mini mini ruhlarımız da, dinin ve Tanrı'nın gerçekliğini sarsılmaz bir hakikat gibi görmüş, duymuş ve yaşamıştı.” (Karatay, 1943: s.8).

Namdar Rahmi’nin mizacını şekillendirenlerden biri de babası Rahmi Beydir. Çocukluğundan beri eğitimiyle ilgilenen baba Rahmi Bey, onun eğitim hayatının başarılı geçmesini sağlamış ve ona okuması için pek çok kitap tedarik etmiştir. Fakat kitap okuma ve yazma konusunda şüphesiz şairin en çok etkilendiği şahsiyet, yakın arkadaşı ve üstadı kabul ettiği Naci Fikret’tir. Şairden bir sınıf ileride olan Naci Fikret, "Ufk-u Âtî" isminde edebî bir mecmua çıkarmaktadır. Bu dergide yazılar yazan Naci Fikret, şairi âdeta büyülemiştir. O zamanlar tuttuğu hatıra defterine şair, şu notu düşmüştür:

“15 Nisan 1911-Arkadaşım Tevfik’le yeni çıkan (Ufk-u Âtî)'yi karıştırdık. Orada (Observasyon) serlevhalı, Naci Fikret imzalı, gayet güzel felsefî bir manzume vardı. -Mezkûr Naci yedinci sınıftadır.” (Karatay, 1952b: 23).

Namdar Rahmi'yi, Naci Fikret'in “Ufk-u Âtî”de yazmış olduğu “Mudhike-i Nisaiyet” (Kadınlık Komedisi) başlıklı yazısı çok etkilemiştir. Naci Fikret'le bu yazı sayesinde tanışan Namdar Rahmi, ona olan hayranlığını ölümüne kadar artarak sürdürmüştür. Sadece yazılarıyla değil hâl ve hareketleriyle de Naci Fikret, Namdar Rahmi'yi âdeta büyülemiştir. Şair, Naci Fikret’teki "bilgi ve olgunluk" sebebini şöyle keşfeder:

"Onun kitaplara pek çok şey borçlu olduğunu ve manevi olgunluğunun ancak kitaplar sayesinde olabileceğini anlayınca ta içimden müthiş bir şekilde sarsılmıştım.” (Karatay, 1952b: 17).

$\mathrm{Bu}$ etkilenmeyle beraber kitap temin etme arzusuyla yanan şair, Afyon'daki kitapçı dayısının oğlu Niyazi vasıtasıyla bir koli kitap sahibi olur. Fakat bu kitaplar onun istediği türde kitaplar değildir. O, daha çok ilmî kitaplar ister fakat ona gelenler "günün modasına uygun olsun diye neşredilen all, yeşilli aktüalite kitapları"dır. Bu tecrübe onun İstanbul'a gidip sahaflardan ve kitapçılardan "göre göre, beğene beğene kitap” almak iştihasını artırır. Namdar Rahmi, kitaplara olan ilgisini de şöyle anlatir:

"Ben kitapları çok sevdim. Bu sevgimin hakikaten bir aşk ve iptilâ halinde tecelli ettiği zamanlar oldu. 1914 Cihan Harbi başlamazdan evvel Konya'da idim. Gençliğin en coşkun ve dinamik devresinde ruhumu saran ateş, kitap aşkının ateşi idi. Şurasını hemen ilave edeyim ki bende esasen mevcut olan temâyülü teskin edilmez bir ihtiras haline getiren mütefekkir arkadaşım Naci Fikret olmuştur.” (Karatay, 1952c: 17).

Namdar Rahmi’nin önemli mizaç özelliklerinden bir diğeri de onun öğrenme ve öğretme tutkusunun hiçbir zaman kaybolmamasıdır. Kendisini geliştirmek için sürekli kitap alması ve onları büyük bir iştiha ile okuması yanında; öğrendiklerini başkalarına özellikle öğrencilerine öğretmesi ve hayatında uygulaması önemli bir hassa olarak göze çarpmaktadır. Öğretmenlikten ihraç edildikten sonra, tekrar bu mesleğe dönme çabaları da onun bu yönünü bariz şekilde gösterir. Şair, Naci Fikret’le tanıştıktan sonra kitap okuma arzusuyla yanıp tutuşmaktadır. Namdar Rahmi ve Naci Fikret, Konya'da bir arkadaş grubu meydana getirmişlerdir. Grup, daha çok Alaaddin Tepesi, Dede Bahçesi ve İstasyon semtlerinde buluşurlar. Bu gençler arasında, Namdar Rahmi'den başka Mehmet Nuri, Ali Ragıp, Naci Fikret de vardır. Bunlar buluştuklarında daha çok birbirlerine şiir okurlar. Namdar Rahmi, bunu şöyle ifade eder:

“Bu müşâarelerde Naci’nin mısraları, rindane bir hakikate, filozofik bir ifade verir; Ragıp’nkiler, derin ve esrarlı bir hayal âleminde uçan bir kartalın keskin kanat vuruşlarını andırır; Nuri'ninkiler

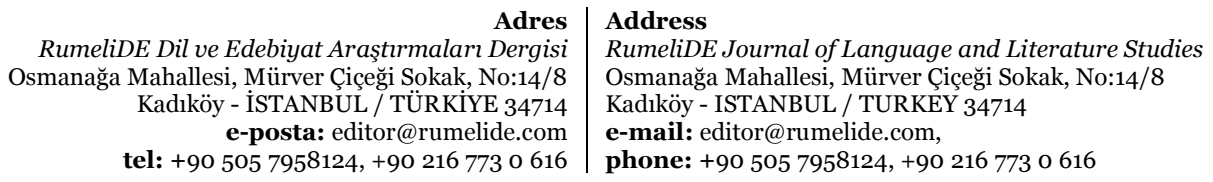


de ise ciddi bir eda ile hadiselere kabak durduran alaycı bir ruhun akisleri görülürdü.” (Karatay, 1952b: 90-91).

1915’te mezkûr isimler, “mukadderatın savurduğu rüzgârlarla birbirlerinden” ayrılırlar. O, daha çok Tevfik Fikret'e hayrandır. Fakat Ali Ragip'ın tesiriyle de "Divan Edebiyat zevkini” tadar. Onun etkisiyle "gazeller, mesneviler yazar." (Karatay, 1954: 10).

Konya'da İttihat ve Terakki Fırkası'nın propagandasını yapan, “Osmanlı” gazetesini de çıkaran Rasim Haşmet, bir öğretmen olarak da Namdar Rahmi ve Naci Fikret ile ilgilenmiştir. "Asil ve necib insan ruhu; teklifsiz ve samimi hal ve tavırları ile” Namdar'la birlikte Naci'yi kendisine bağlamıştır. Şair, “M. Rahmi” imzası ile etkilendiği bu öğretmenin,

\begin{abstract}
"Osmanlı gazetesinde yazılar yazmıștır. Fakat harp içinde İstanbul'a dönen Rasim Haşmet'in orada ve aynı yıl genç yaşında tifüsten öldüğünü işitir. O zaman Namdar, Afyon İdadisi Tarih-Coğrafya öğretmenidir. 17 yaşında, zayıf, ufak-tefek yapılı ve gösterişsizdir.” (Karatay, 1952a: 79).
\end{abstract}

(Karatay, 1952a: 79). Namdar, Naci, Mehmet Nuri ve Ragıp'ın savaş yıllarında derince etkisinde kaldıkları bir diğer şahsiyet ise Hüseyin Kâmi'dir. Hüseyin Kâmi, Aka Gündüz'le birlikte İttihat ve Terakki Hükûmeti’nin Konya’ya sürdüğü bir edebiyatçıdır. O, harp ylllarında "İstanbul'da bir muhalefet havası yaratması, kitleyi sürüklemesi ihtimali” düşünülerek sürgün edilmiştir. Namdar ve arkadaşları, Hüseyin Kâmi ile birlikte Konya'da bir Türklük derneği kurarlar. Her biri de bir Türkçe ad alırlar. H. Kâmi, İttihat ve Terakki’nin endişelendiği kadar vardır. O,

"bir parti, bir cemiyet için çok mühim bir kuvvettir. Mütenasip boy-posu, zarif, itinalı giyimi, ruhi, manevi vekar ve azameti ile Konya'da "vilayet erkânını, memleketin münevver zümresini, gençleri birden bire tılsımlı bir kuvvet gibi kendine bağlayıvermiştir.” (Karatay, 1952b: 85).

Namdar Rahmi Karatay, o günleri ise şöyle anlatır:

"Ben ve arkadaşlarım, siyasi cereyanlara ve ihtiraslara tamamiyle bigâne olduğumuz için onunla münasebetimiz tamamiyle hasbi bir sanat ve edebiyat zevkini tatmak içindi. Biz onun niçin burada bulunduğunu bile düşünmeksizin büyük bir heyecanla onun inşad-ı musikisine koşardık.” (Karatay, 1952b: 85).

"Dehrî" mahlash şïrler yazan Kâmi, aslen Dağistanlı'dır. Konya'da Gazi Âlemşah Mahallesi’nde bir evde pansiyoner kalmaktadir." (Karatay, 1952b: 83). Konya'dan bir konuşmasında, "sürgün hayatından şikâyet ettiği” için Karaman'a, oradan da Bozkır’a gönderilip bir hastahane köşesinde “tifüsten ölüp” (Karatay, 1952b: 88) giden Hüseyin Kâmi'nin “edebiyat zevkini” kazandırma bakımından Namdar Rahmi ve arkadaşlarına etkisi büyük olmuştur.

\title{
2. Namdar Rahmi Karatay'ın eserleri
}

\subsection{Felsefî meslekler vokabüleri:}

Afyon'da 1932 yılında basılan bu eser liseler için hazırlanmış küçük bir felsefe sözlüğüdür. Yazar bu eserini yazarken, kendi ifadesine göre Fransız felsefecilerinden Lalande'ın lügatinden faydalanmıştır. Ancak Afyon'da basılması eserin tanınmasına engel olmuştur. Yeni harflerle basılan ilk felsefe sözlüğü olması açısından Türk felsefe tarihinde önemli bir değeri vardır. Eserdeki maddeler daha çok enerjetizm açısından değerlendirilmiş ve yorumlanmıştır. Eser 2018 yılında, Recep Alpyağıl tarafından yayına hazırlanarak İz Yayıncılık tarafından yayımlanmıştır.

\begin{tabular}{r|l} 
Adres & Address \\
RumeliDE Dil ve Edebiyat Araşttrmalar Dergisi & RumeliDE Journal of Language and Literature Studies \\
Osmanağa Mahallesi, Mürver Çiçeği Sokak, No:14/8 & Osmanağa Mahallesi, Mürver Çiçeği Sokak, No:14/8 \\
Kadıköy - İSTANBUL / TÜRKIYE 34714 & Kadıköy - ISTANBUL / TURKEY 34714 \\
e-posta: editor@rumelide.com & e-mail: editor@rumelide.com, \\
phone: +90 505 7958124, +90 2167730616
\end{tabular}




\title{
2.2. Namık Kemal ve idealizmi-sosyoloji ve psikoloji bakımından bir etüt:
}

Şairin Bursa Halkevi’nde, Namık Kemal'in yüzüncü doğum günü münasebetiyle verdiği konferans metninin bir kitapçlk şeklinde basılmış halidir. 1941'de basılan ve 28 sayfadan oluşan eserde, "Namık Kemal'in vecd hâline gelen idealizminin, vatan ve millet aşkının bir mistisizme vasıl olduğunu açılayan dikkate değer yorumlar" yapılmıştır. Eserde, Namık Kemal’in idealist yönü enerjetizm açısından değerlendirilmiştir. Bu eseri için şair, Millî Eğitim Bakanlığı tarafından takdirname ile ödüllendirilmiştir.

\subsection{Yazma dersleri:}

1945 yllında İstanbul'da Maarif Matbaası tarafindan basılan eser, 273 sayfadan ibarettir. Bu kitap, Sorbon Üniversitesi'nde edebiyat profesörü olan Daniel Monet'nin bu konudaki kitabını temel alarak yazdığı bir ders kitabıdır. Eser, Gazi Terbiye Enstitüsü ve lise öğrencileri için hazırlanmıştır. Bu sebeple kitap, Maarif Matbaası tarafından kırk beş bin adet basılmıştır. Eserin sonunda bulunan "Açıklamalı sözlük ve endeks" dilimiz açısından da kıymetlidir. Yazar, bu eserini kaleme alırken dile büyük önem verdiğini ifade eder ve "sav, kılgı, kanıt, evrim, yabansı, imgelem, aytışmak, imgesel” gibi o dönem pek kullanılmayan arkaik kelimeleri de kullanır.

\subsection{Kitaplarımın hikâyesi:}

1952'de İstanbul'da basılan ve 102 sayfadan müteşekkil eserde, Namdar Rahmi, kitapların dünyasıyla ilk defa nasıl karşılaştığını anlatmaktadır. Kitap, Konya'nın II. Meşrutiyet devri matbuat, edebiyat ve fikir hayatında önemli bir yer edinmiş genç şahsiyetleri hakkında kıymetli bilgiler verir. Bu yönüyle eser, Konya'nın yakın kültür tarihi yönünden vazgeçilmez bir değer taşır. Şair, kendi hayatında değerli bir yeri bulunan isimlerden Naci Fikret (Baştak), Ali Ragıp, Mehmet Muhlis (Koner), Mümtaz Bahri (Koru), Mehmet Nuri (Gençosman), Rasim Haşmet ve Hüseyin Kâmi hakkında başka kaynaklarda bulunmayan bilgiler vermiştir. Eser,

\begin{abstract}
“Namdar Rahmi’nin Konya'daki hayatı, yetişmesi, arkadaşları, Fransa'dan dönüşü ve Bursa hatıralarını içine almaktadır. Devrin kültür hayatını, Namdar Rahmi ve Naci Fikret'le ilgili birçok psikolojik motifi yansıtması açısından ilginçtir.” (Muşta, 1990: 142).
\end{abstract}

\subsection{Paris Mektupları:}

1952'de İstanbul'da basılan eser, 133 sayfadan ibarettir. Kitaptaki yazılar, şairin Paris hatıraları, Fransız hayatı ve kültürü ile özellikle Fransa ve Belçika'da yaptığı seyahate dair yazılarını içermektedir. Bu kitabın son paragrafı, yaptığı seyahatin kendisinde uyandırdığı duyguları ifade etmesi bakımından önem arz eder:

"Biliyorum ki dünyada yüzbinlerce milyonlarca kasaba var. Anladım ki bunların hiçbirisinde aradığım beklediğim şey yoktur. O yine benim içimdedir. Benim öz yurdumdadır. İște şimdi bu kanaatle mutmain ve müsterih seyahatten avdet ediyorum." (Aktaran: Birinci, 2012b: 41).

\subsection{Geçti Bor'un Pazarı:}

Bu eser geniş olarak inceleneceği için burada tekrara düşmemek adına açıklamalara yer vermiyoruz.

\begin{tabular}{|c|c|}
\hline & \\
\hline aları $D$ & d Literatur \\
\hline $\mathrm{Mal}$ & Mahallesi, Mürver Çiçeği Sokak, No:14/8 \\
\hline Kadıköy & STANBUL / TURKEY 34714 \\
\hline $\begin{array}{r}\text { e-posta: edito } \\
\text { tel: }+905057958124,+\end{array}$ & $\begin{array}{l}\text { editor@rumelide.com, } \\
\text { +90 505 7958124, +90 } 216773 \text { o } 616\end{array}$ \\
\hline
\end{tabular}




\title{
3.Şiirlerin içerik/muhteva yönünden incelenmesi
}

Namdar Rahmi Karatay'ın hiciv şiirlerini topladığı "Geçti Bor’un Pazarı" adlı kitabı, 1952 yılında basılmış ve 31 sayfadan oluşan, 1933 senesinden itibaren yazdığı mizahi şiirlerini ihtiva etmektedir. Bu kitabın ilk baskısında, yirmi yedi ve daha sonra ölümünün birinci yıldönümünde, ikinci basımında ${ }^{4}$ ise yirmi dokuz şiir bulunmaktadır. Şairin vedası mahiyetindeki yazısı, kardeşi Sadrettin Karatay tarafından tamamlanarak yayımlanmıştır. Yazı şöyledir:

\begin{abstract}
"Bugün müsveddelerini hazırladığım destanlar otantiktir, yalnız birkaçını bulamadım, ölüm de başucumda bekleyip duruyor... Mesela "Uğraş didin nafile, dipsiz anbar boş kile" bentli bir yazım vardı, bulamadım. Bir de "Aptal ata binince bey oldum sanır, şalgam suya girince yağ oldum sanır" bentli bir terciim vardı, onu da beyaza çekemedim. Ölmeden bunları başarabilirsem bu da benim için bir hatıra olacaktır. Şu satırları yazarken kendimi hiç iyi hissetmiyorum, damar sertliği alıp yürümektedir." (Karatay, 1954: 14).
\end{abstract}

Ancak son senelerde yapılan üçüncü baskısında5 da ikinci baskı metni aynen kalmış, fakat kitabın ismi dış kapağında "Leyleğin Ömrü” ibaresi üst, iç kapakta ise alt başlık olarak eklenmiştir. Şiirleri içerik yönünden incelediğimizde, şairin çokça sosyal tenkitte bulunduğu görülür. Ayrıca, kendisini eleştirdiği şiirlerine de bolca rastlanır. Her bir şiir farklı olay ve kişilere atıfta bulunduğu için, metinleri içerik yönünden geniş olarak inceleyerek bir sonuca ulaşacağız.

Kitaba adını veren "Geçti Bor’un Pazarı" adlı ilk şiirde şair, fırsatların elden kaçırılması, gençliğin boşa harcanması, şanssızlık ve hayal kırıklığından şikâyet eder. Şiirde makam ve mevkiye gereğinden fazla rağbet edilmesi, bilginin değersizliği, beceri ve yeteneğin önemsizliği eleştirilir. 1933 yllında Bursa'da kaleme alınan, ilk kez Akbaba dergisinde 1934 tarihinde "Eşekarısı"6 müstearıyla yayımlanan bu şiir, Namdar Rahmi’ye kısa sürede şöhreti getirmiştir.7

"Başta kavak yelleri estiği günler hani?

Umduğumuz neşeler, şerefler, ünler hani?

Beklenilen alayl, şanlı düğünler hani?

Selvi gibi ümitler döndü birer iğdeye,

Geçti Bor’un pazarı, sür eşeği Niğde’ye!” (s. 17-18)

Kitabın ikinci şiiri “Poker Destanı"dır. Bursa'da 1935'de yazılan şiir, “Eşekarısı” müstearıyla 1937'de Akbaba dergisinde "Hayat Pokeri!" adıyla yayımlanmıştır. ${ }^{9}$ Kaderin cilvesiyle kaybeden bir insanın ruh hâlinin tasvir edildiği ve hayatın bir kumar oyununa benzetildiği "Poker Destanı" adlı şiirde, ömrün boşa harcanması eleştirilir. Şairi hicve yönelten ve şiirlerinde sıklıkla elden kayıp giden hayattan

(1954, Ankara: Türkiye Matbaacılık ve Gazetecilik Anonim Ortaklığı, 80 s.)

(2004, İstanbul: $78 \mathrm{~s}$.)

Eşekarısı (1934), "Geçti Bor’un Pazarı", Akbaba, 8 Şubat, (6), 6.

Şair, kendisinin tanınmasını sağlayan bu şiirin yazılış hikâyesini şöyle anlatır: "1933 baharında, Bursa'da birtakım arkadaşlarla bir sinema matinesine gitmiştik, karşıdan Emir Sultan’n servileri görünüyordu. Bilmem yıllarca süren hayal kurkklı̆ının etkisiyle midir, aklıma bir beyit geldi:

Servi gibi ümitler döndü birer iğdeye,

Geçti Bor’un pazarı, sür eşeği Niğde’ye!

dedim ve bunu sinemanın karanhğında sigara paketinin arkasında tamamladım. Ertesi gün mizahi manzume bir yıldırım hizıyla yayıld, bir arkadas bunu tape ettirerek Akbaba'ya göndermis. Meğer milletin bir yarasına dokunmuşuz. Bu mizahi yazı az zamanda bütün Türkiye'ye yaylld ve bana yeni bir stil verdi. Her yerden bu vadide manzumeler yazıliyor, benimkine nazireler yapllyordu" (Karatay, 1954: 13).

8 Bu yazıdaki tüm alıntı şiirler, Namdar Rahmi Karatay’ın Geçti Bor’un Pazarı isimli kitabının 1954 yılındaki ikinci baskısından alınmıştır.

Eşekarısı "1937", "Hayat Pokeri”, Akbaba, 12 Mart, (166), 7.

Adres $\mid$ Address

RumeliDE Dil ve Edebiyat Araşttrmalar Dergisi $\quad$ RumeliDE Journal of Language and Literature Studies Osmanağa Mahallesi, Mürver Çiçeği Sokak, No:14/8 Osmanağa Mahallesi, Mürver Çiçeği Sokak, No:14/8

Kadıköy - İSTANBUL / TÜRKIYE 34714 Kadıköy - ISTANBUL / TURKEY 34714 e-posta: editor

e-mail: editor@rumelide.com

tel: +90 505 7958124, +90 2167730616 phone: +90 505 7958124, +902167730616 
şikâyet ettiren nedenler arasında, yaşadığı talihsizlikler yer almaktadır. Bu şiirde de "Balarısı olmadım, oldum eşek arısı" dizeleriyle onu büyük bir yıkıma uğratan bu talihsizliklerden birine gönderme yapılır. Sorbonne'dan döndükten sonra Konya Erkek Lisesi’nde felsefe öğretmenliği yapan Namdar Rahmi Karatay, arkadaşının çıkardığı "Balarısı" adlı dergiye bir yazı gönderir. Yalnız ahlaka mugayir gerekçesiyle dergi toplatılır; şair de arkadaşıyla birlikte derginin sahibi zannedilerek görevinden ihraç edilir. Bu talihsiz olaydan sonra karamsarlığa kapılan şair, büyük uğraşlardan sonra çok sevdiği öğretmenlik mesleğine geri dönse de bunun etkisinden uzun süre kurtulamaz. Şiirin önemli bir özelliği de, "gibi" edatının tam on beş kez takrar edilerek, kuvvetli bir muhteva-ahenk ilişkisi sağlanmış olmasıdır. Buradan da anlaşılıyor ki şair, kendisini kumar terimlerinden hemen hemen hepsine benzetmiştir. Bu şiir hakkında, Necati Tonga'nın bir yazısı "Kumar" kitabında yayımlanmıştır. ${ }^{10}$

"Saadet uma uma geçti ömrümün yarısl,

Bilmem niçin düşmüyor başımıza darısı,

Balarısı olmadım, oldum eşek arısı,

Herkes çalım satarken canlı bir afiş gibi,

Ben kendimi harcadım beş paralık fiş gibi...”(s.19-20)

Bursa'da 1935’te yazılan "Âşılklık Ne Halına” adlı üçüncü şiirinde, gönül işlerinde başarılı olamadığını dile getiren şair, kara bahtından yakınmaya devam eder. Her işini rahatlıkla yürütenlere gıpta ile bakarak dünyada her şeye gönül bağlanmamasını hatırlatsa da düzene ayak uyduramadığı için kendisini tenkit eder.

“Gönül sen ne sersemsin, ne körsün, ne sakarsin,

Yulaksız bir su gibi her güzele akarsin,

Neye sebepsiz yere yüreğini yakarsın,

Göz koymaktan ne çlkar elin günün malına,

Çapıtına çuluna, âşıklık ne halına.”(s.21-22)

"Karaman’ın Koyunu”11 adlı dördüncü şiirde insanlara dilini tutması, gönlünü herkese açmaması ve başkalarının işlerine karışmaması gibi konularda şair tarafından öğüt verilirken, genel olarak birine

10 Tonga, Necati (2020), "Kederli Bir Hayatın Muhâsebesi: Namdar Rahmi Karatay ve Poker Destanı”, Kumar Kitabı, Emine Gürsoy Naskali (Ed.). İstanbul, Kitabevi Yayınları, 303-318.

Bu atasözüyle ilgili iki efsane vardır:

1.Efsane: Karaman'ın kalesini kuşatan düsmanlar geceyi beklemeye başlarlar. O gece Karamanoğlu Beyliği'nin askerleri başka seferdedir. Kaleyi savunacak yeterli asker yoktur. Düşünüp taşınan yaşlllar ve ileri gelenler bir kurtuluş yolu bulmaya çalıșırlar. Bir çoban "Bakın der Karaman"da ne kadar koyun, koç varsa toplayalım boynuzlarına fenerler takıp bayır aşağı sürelim. Düşman, çok kalabalık olduğumuzu sanır, belki kuşatmayı kaldırır” der. Çobanın dediği yapılır. Boynuzları ışıklı sürü aşağı inmeye başlayınca, düşman askerleri büyük bir ordunun üzerine geldiğini sanarak kaçmaya başlarlar. Durum sonradan anlaşılınca da iş işten geçmiştir. "Karaman’ın koyunu, sonra çıkar oyunu" deyişinin bu olaydan rivayet edildiği söylenir.

2.Efsane: Karamanoğulları Beyliği Moğollarla sık sık savaș hâlindedir. Moğollar Karaman Beyliği üzerine sefer düzenlerler ve beylik sınırında gecelerler. Tam bu sırada, Karamanoğulları Beyliği askerleri koyun postlarını üzerlerine giyerler ve bazıları boyunlarına çan takarak bir koyun sürüsü havasını verirler. Bu şekilde tam teçhizatlı olarak düşman üzerine doğru varırlar. Moğol askerleri akșam eğlencesinde olup, gelenin gerçek bir koyun sürüsü olduğunu zannederek aldırmazlar. Gelen Karamanoğulları askerleri ayağa kalkıp, postları sıyırarak Moğol askerlerini bozguna uğratırlar. Moğol askerlerinden canını kurtaranlar memleketlerine vardıkları zaman "Karaman’ı Koyunu Sonra Çıkar Oyunu" demişlerdir. Efsanenin bu olaydan kaynaklandığı rivayet edilmektedir.

(https://kulturportali.gov.tr/turkiye/karaman/kulturatlasi/karamanin-koyunu-sonra-cikar-oyunu-efsanes) (Erişim Tarihi: 18.02.2021)

RumeliDE Dil ve Edebiyat Araşttrmaları Dergisi Osmanağa Mahallesi, Mürver Cicceği Sokak, No:14/8 Kadıköy - ISTANBUL / TÜRKIYE 34714 e-posta: editor@rumelide.com tel: +90 $5057958124,+902167730616$
Address

RumeliDE Journal of Language and Literature Studies Osmanağa Mahallesi, Mürver Çiçeği Sokak, No:14/8

Kadıköy - ISTANBUL / TURKEY 34714

e-mail: editor@rumelide.com,

phone: +90 $5057958124,+902167730616$ 
kolayca güvenmek eleştirilmektedir. Bursa'da 1935 yllında kaleme alınan şiir, Akbaba dergisinde “Eşekarısı” müstearıyla 1940’da yayımlanmıştır. ${ }^{12}$

“Oğul sana bir öğüt vereyim, dinle beni,

Ağzın açma sakın açarsan aç keseni,

En candan bildiklerin tefe koyarlar seni,

Birer birer denedik olgununu, toyunu,

Karaman’n koyunu sonra çıkar oyunu.”(s.23-24)

Bursa'da 1935'te yazılan ve kitaptaki beşinci şiir olan "İşte Geldik Gidiyoruz" adlı metnin bütününde; başta dünya düzeni olmak üzere kolay yoldan para kazananlar, sahte kahramanlar ve hızlıca yükselenler eleştirilirken gençliğin boşa harcanması, dünyanın geçiciliği, kişinin değerinin bilinmemesi, boş yere umut besleme, emeklerin karşılığını alamamaktan duyulan rahatsızlık dile getirilir. Şair, şiirinde hayattan beklentilerinin karşılanmadığından yakınırken; kendi iç dünyasında tam bir "hayal -hakikat" çatışması yaşamıştır. Şairi bu yönüyle Halit Ziya Uşaklıgil’in önemli eseri “Mai ve Siyah”taki kahramanı "Ahmet Cemil” benzetebiliriz. Her iki karakter de yaşadıkları hayat boyunca hayallerini gerçekleştirememiş, hakikate boyun eğmişlerdir. Metnin bir başka özelliği de, bize Âşık Garip’in Halep için yazdı ̆̆ı, meşhur "İşte Geldim Gidiyorum"13 adlı şiirini hatırlatmasıdır. Bu sebepten ötürü, Namdar Rahmi'nin adı geçen şairden de etkilenmiş olduğu kanaatini taşıyoruz.

"Yüze geldi düne kadar köşesinde keyif çatanlar,

Vatansever oldu çıktı başımıza kaltabanlar,

Bizler bugün buyruk kulu, onlar ise kahramanlar,

Biz batakta köprü olduk, başkalarn geçti nehri,

İşte geldik gidiyoruz, şen olasin Halep şehri.” (s.25-26)

Kitapta yer alan altıncı şiir, “Çarşambadır Çarşamba” Bursa'da 1935 yılında yazılmıştır. Metinde; bu âlemde rahat yaşamak, iş hayatında kolayca yükselmek ve bulunduğu yeri muhafaza etmek için gerçekleri söylemenin pek bir işe yaramadığına dikkat çekilirken, nabza göre şerbet verenler, üstlerine hoş görünenler, günü kurtaranlar, içi boş âlimler, koşulsuz itaat edenler eleştirilir. Ayrıca bu şiirle ilgili Ali Birinci tarafından anlatılan bir de anektot vardır:

“Çarşambadır Çarşamba” gibi bazı şïrleri de halk fikralarına atıfta bulunmakta ve zamâneye uymanın mizahî felsefesini yapmaktadır. Burada "Baktın zamâne uymadı sen uy zamâneye" sözüyle de ifade edilen eyyamcllk felsefesini anlatan fikra, bilindiği takdirde bu şiir bir yoruma kavuşabilir. ${ }^{14}$ Hikâye şöyle:

İki büklüm bir ihtiyar, kasaba pazarından köyüne dönmekte geç kalınca yol üzerinde bir değirmende gecelemek zorunda kalmış. Gece yarısı bir gürültüyle uyandığı zaman, perilerin “Çarşambadır Çarşamba” tekerlemesiyle oyun oynadiğını görmüş. Kendisini fark eden periler, kendisini de oyuna katmışlar. $O$ da "Çarşambadır Çarşamba" diyerek oyunu tamamlamış. Bunun üzerine periler: "Bu ne kadar uysal bir adam” demişler ve mükâfaten kamburunu düzeltmişler ve

$12 \quad$ Eşekarısı (1940), "Karamanı’ın Koyunu”, Akbaba, 28 Mart, (323), 5.

13 Adı geçen şiir şöyledir: İște geldim gidiyorum, /Şen olasın Halep şehri. /Çok ekmeğin tuzun yedim, /Helâl eyle Halep şehri. /Sana derler Arabistan, / Dört tarafın bă̆ u bostan, /Haber geldi nazlı dosttan, /Durmak olmaz Halep şehri! /Âşı Garip düştü yola, /Hızır yardımcısı ola, /Göründü gözümüze sıla, /Sen kal bunda Halep şehri. (Arısoy, M. Sunullah (1985), Türk Halk Şiiri Antolojisi, Ankara: Bilgi Yayınevi, s.56.)

14 Bu hikâyeyi yeri geldikçe hikâyeler anlatmayı seven merhum babamdan dinleyeli yarım asrı geçti. Birinci, Ali (2012), "Namdar Rahmi Karatay'ın Hikâyesi”, Türk Yurdu, Eylül, 32 (301), 42.

Adres $\mid$ Address

RumeliDE Dil ve Edebiyat Araşttrmaları Dergisi $\quad$ RumeliDE Journal of Language and Literature Studies Osmanağa Mahallesi, Mürver Çiçeği Sokak, No:14/8 Osmanağa Mahallesi, Mürver Çiçeği Sokak, No:14/8

Kadıköy - İSTANBUL / TÜRKIYE 34714 Kadıköy - ISTANBUL / TURKEY 34714 e-posta: editor@rumelide.com

e-mail: editor@rumelide.com

tel: +90 505 7958124, +90 2167730616 phone: +90 505 7958124, +902167730616 
yola koymuşlar. Bunu gören ve durumu öğrenen başka bir kambur da değirmende ertesi gün gecelemiş. Aynı şekilde oyuna davet edilen ihtiyar, günün şarkısı "Perşembedir Perşembe" iken o yine arkadaşından öğrendiği şekilde, "Çarşambadır Çarşamba" demeye devam etmiş. Periler oyun sonunda: "Bu ne aksi bir herif" demişler ve kamburuna bir kambur daha eklemişler. ${ }^{15}$ (Birinci, 2012b: 42).

"Ey oğul bu âlemde maksadın yaşamaksa

Al sana hiç modası geçmiyen bir siyasa,

Bu sözü iyi belle, olsun sana bir yasa,

İşte her yer süt liman, her işimiz gül pembe,

Çarşambadır çarşamba, perşembedir perşembe.” (s.27-28)

“Düşün Deli Gönül Düşün” adlı yedinci şiirde herkesin kendi çıkarını düşündüğü, riyakâr, bencil ve vefasız insanlarla bozuk dünya düzeni eleştirilmektedir. Şiir, yine Bursa'da 1936 senesinde yazılmıştır. Şair, şiirinde baştan sona teşhis sanatını kullanarak gönlüyle hasbihâl eder. Şiirde Ziya Paşa'nın etkisi sezilir.

"Ben bilirdim, doğru olmak değişmiyen bir esastır,

Dediler ki, riyakâr ol, geçim yolu iltimastır,

Âlem yine o âlemdir, eski hamam eski tastır,

Şaştım kaldım bu işlere, isterseniz siz de şaşın,

Düşün deli gönül, düşün, adam eşek mi alır kışın!” (s.29-30)

Kitabın sekizinci şiiri olan, Bursa'da 1936'da kaleme alınan "Hani O Günler" adlı metinde; zamanın hızla akıp gitmesine rağmen değişmeyen dünya düzeninden şikâyet edilir ve ağır yükler altında ezilen insanoğlunun gerçeklerle bir türlü yüzleşememesi eleştirilir. Şiirin içeriğinde çok fazla "tezat" sanatına yer verilmiştir. $\mathrm{Bu}$ da şairin, "hayal-hakikat" çatışmasını kendi iç dünyasında şiddetli olarak yaşadığının bir göstergesidir. Namdar Rahmi, eski günlerine özlem duyar. Şu an içinde yaşadığı hayat gerçek âlem "hakikati", geçmişte yaşadığı güzel günleri yâd etmesi "hayal"i temsil eder. Bu tür metinlerde, şairin Servet-i Fünun Edebiyatı döneminde kullanılan temaları işlediğini görüyoruz. Şiirin nakaratı olan "Devran yine o devran, âlem yine o âlem" sözleri, Recaizade Mahmut Ekrem tarafından kaleme alınan "Ferdâ-yı Tedfîn”"16 adlı şiirde de yer almaktadır. Namdar Rahmi'nin, Tevfik Fikret başta olmak üzere Servet-i Fünun şairlerinden etkilendiğini düşünürsek, bu edebî ekolü hazırlayan kişi olan Recaizade Mahmut Ekrem'den de istifade etmesi gayet normaldir. Buna benzer sözler, meşhur heccav Ziya Paşa'nın şiirlerinde de mevcuttur.

"Bu âlem eskiden de bu kadar çorak miydı?

Bugünkü kara kara, bugünkü ak ak mıydı?

Hâsılı şimdikinden hiçbir fark yok muydu? 15 Bu hikâye ve şiir bir devrin değil, beşerin değişmez bir gerçeğini ifade etmektedir. Şiirimizde başka örnekler de
bulunabilir. "Merhaba kör kadı" diyeni seven insan henüz anasından doğmamıştır ve doğmayacaktır. (Birinci, Ali (2012), age, s.33.)

16 Manzumenin il bendi şöyledir: A'mâr-ı beşer her gün her dem bulur noksân. /Âsârı da fânidir onlarda da var pâyân. /Bir yandan olur peydâ bir yandan olur pinhân. / Kendi gibi devrânı bitmekte sanır insân. / "Âlem yine ol âlem devrân yine ol devrân”. Bu şiirin tam metni için bakınız: Recaî-zade M. Ekrem (1997), Bütün Eserleri II, (Haz.) İsmail ParlatırNurullah Çetin, Hakan Sazyek, İstanbul: Milli Eğitim Bakanlığı Yayınları, s.333.

Adres | Address

RumeliDE Dil ve Edebiyat Araşttrmaları Dergisi $\quad$ RumeliDE Journal of Language and Literature Studies Osmanağa Mahallesi, Mürver Çiçeği Sokak, No:14/8 Osmanağa Mahallesi, Mürver Çiçeği Sokak, No:14/8

Kadıköy - İSTANBUL / TÜRKIYE 34714 Kadıköy - ISTANBUL / TURKEY 34714 e-posta: editor@rum tel: +90 505 7958124, +90 2167730616 phone: +90 505 7958124, +90 2167730616 
Bilmem ki, nasıl yazmış bunu keskin bir kalem?

Devran yine o devran, âlem yine o âlem.” (s.31-32)

Kitabın dokuzuncu şiiri olan "Kırk Gün Taban Eti”, Bursa'da 1936 yılında yazılmıştır. Metinde; hayatın bir av macerasına benzetildiği, şanslı olmanın yanında emek ve alın teri olmadan kazanç elde etmenin doğru olmadığı dile getirilir ve hayatın her alanında rahatlıkla görülebilen -"şakşakçılar, tuzakçılar, tavcılar, yavru baz taşıyan göz bağıcılar, gözleri sürmeli hacılar”... gibi- kolay yoldan kazanç sağlamaya çalışanlar eleştirilir.

"Her alanda olur, türlü avcllar,
Şakşakçlar, tuzakçılar, tavcılar,
Yavru baz taşıyan göz bağıcllar,
Gözleri sürmeli nice hacılar,

Hepsi de sabirla bekler kısmeti,

Kirk gün taban eti, bir gün av eti." (s.33-34)

"Sen Bir Garip Çingenesin” isimli onuncu şiirde; ekonomik düzen ve sosyal adaletsizliğin eleştirildiği görülür. Şiir, 1937 yılında Bursa'da kaleme alınmış olup metinde açıkgözlüler, emek hırsızları, kolay yoldan zengin olanlar, hazır yiyiciler, nüfuzlu kimseler, burjuvalar gibi pek çok yozlaşmış tipten duyulan rahatsızlık dile getirilir. Metinde "nene gerek" ibaresi tam dokuz defa kullanılarak, herkesin kendi yerini bilmesi vurgulanmıştır. Şiir, "piyano" ve "kaval" sembolleri üzerinden Batılllaşmaya çalışan "aristograt"larla onlara direnen "halk"ın karşılaştırılmasından ibarettir.

"Çadır senin nene yetmez, tutturmuşsun villa diye,

Üzüyorsun yüreğini, yat isterim ille diye,

Taştan taşa firlatıyor felek seni bilye diye,

Ne anlarsin piyanodan, çal kavah eğlenerek,

Sen bir garip çingenesin, telli zurna nene gerek...”(s.35-36)

On birinci şiir, Bursa'da 1937'de yazılmış olan "Leyleğin Ömrü”dür. Boşa geçen ömrün ardından hayıflanılan ve kaderden şikâyet edilen şiirde; vaktini sürekli boş boş konuşarak geçirenler, boş hayaller peşinde koşanlar, güce değer verip güçsüzü ezenler, makam-mevki sarhoşluğuyla herkesi öven şakşakçılar eleştirilir. Metindeki bazı dizeler Şeyhî’nin "Harnâme"17 adlı hiciv türünde kaleme aldığı eserini hatırlatır. Örneğin; "Kol, kanad, kelle ve boynuz, kuyruk" gibi mısral. Şiirdeki "bülbülün inleyerek devrinin bitmesiyle" liyakatli olanların artık sözünün geçmemesine, "çaydaki kurbağanın vakvak" sesi çıkarması ise liyakatsiz insanların boş boş ötmesine benzetilmiştir. "Bülbül”, "kurbağa ve leylek" bu iki insan tipinin sembolüze edilmiş hâlidir.

"Eskiden alna yazılmış bu kader,

Hiçe say varh̆̆ı sen etme keder,

Bülbülün inliyerek devri biter,

17 Daha fazla bilgi için şu esere bakılabilir: Şeyhî (2011), Harnâme, (Haz.) Mehmet Özdemir, İstanbul: Kapı Yayınları.

Adres $\mid$ Address

RumeliDE Dil ve Edebiyat Araştırmaları Dergisi $\quad$ RumeliDE Journal of Language and Literature Studies

Osmanağa Mahallesi, Mürver Çiçeği Sokak, No:14/8 Osmanağa Mahallesi, Mürver Çiçeği Sokak, No:14/8

Kadıköy - İSTANBUL / TÜRKIYE 34714 Kadıköy - ISTANBUL / TURKEY 34714

e-posta: editor@rumelide.com e-mail: editor@rumelide.com,

tel: +90 505 7958124, +90 2167730616 phone: +90 505 7958124, +90 2167730616 
Çaydaki kurbağanin vakvak ile,

Leyleğin geçer ömrü lâklâk ile.”(s.38-39)

"Eşeğe Gem Vurmayın" adlı on ikinci şiirde; her işi zamanında ve yerinde yapmak gerektiği mesajı verilirken, kişiye hak ettiğinden fazla değer vermek eleştirilir. 1937'de Bursa'da yazılan metinde, işini uyduranlar tilkiye benzetilmiştir. İnsan davranışları, hayvanlar sembolize edilerek anlatılmış; "yalan" ise silaha benzetilmiştir. Şiirde, şair tarafından insanlara fazla güven duyulmaması öğütlenmiştir. "Sanır" kelimesi metinde tam on iki kez kullanılmış ve insanların kendisini olduğundan farklı göstermeye çalıştıkları anlatılmıştır. Aynı kelime tüm şiir boyunca vurguyu üzerinde toplayarak âdeta bir musiki gösterisi yapılmıştır.

"Pehpehler, pohpohlarla çok itleri at yaptık,

Uçurduk ta göklere alkıştan kanad yaptık,

Hiç yoktan başımıza koca saltanat yaptık,

Üstüne çul vursanız, it onu kanad sanır,

Eşeğe gem vurmayın, kendisini at sanır." (s.39-40)

Kitabın on üçüncü şiiri, Bursa'da 1938'de kaleme alınan "Harman Sonu Dervişlerin" adlı metindir. Şiirde dünyanın, talihin, şöhretin geçiciliğine vurgu yapılırken önden gitmeye çalışırken yorulmanın, koşturmaca içinde kaybolmanın, kendi hırslarının esiri olmanın anlamsızlı̆̆ı dile getirilir. Metnin içeriğinde "yaz-kış, bugün-yarın, dün-bugün, sıcak-serin" gibi çok sayıda tezat sanatına yer verilmiştir. Şiirde, "şöhret" rüzgâra benzetilerek orijinal bir imaj örneği verilmiştir.

"Şöhret rüzgâr gibi uçar,

Bu dünya tez gelir geçer,

Talih seller gibi kaçar,

Bir gün bilinir değerin,

Harman sonu dervişlerin.” (s.41-42)

1938'de yine Bursa'da yazılan "Komşunun Tavuğu Kaz", kitabın on dördüncü şiiridir. Hakikati görmekte zorlanan insanoğlunun, elindekinin değerini bilmeyip başkalarının sahip olduklarına özenmesinin anlatıldığı şiirde; doyumsuz bir nefsin emrinde çevresindeki insanların hayatlarına, ilişkilerine ve mallarına göz diken insanlar, "devlet” çatısı altına girdikten sonra her yaptıkları takdirle karşılanan amirler, amcası ya da dayısı sayesinde makam-mevki edinenler, devlet malını sömürenler, aile içinde üvey evlat muamelesi gösterenler eleştirilir.

"Hamdolsun esir değil, vatandaşzz bizler de,

Bol bol nefes alriz hürriyetler her yerde,

Kimseye sir vermeyiz, derdimizi gizler de,

Fakat bizim lokmamız büyür aç gözlerde,

Şerbet içsek şampanya, ayran kımız görünür,

Komşunun tavuğu kaz, karısı kız görünür.” (s.43-44)

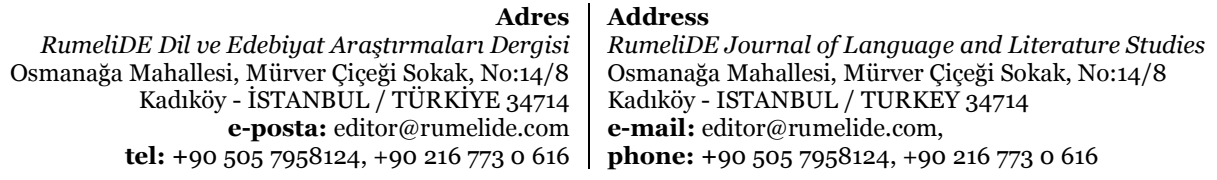


Kitaptaki on beşinci şiir, 1938 'de Bursa'da kaleme alınan "Ölme Eşeğim Ölme"dir. Sabırla dünya düzeninin değişmesini beklerken boşa geçen ömürden şikâyet edilen şiirde, dalkavuk, riyâkâr, ikiyüzlü insanların gösterişli ve çıkarcı dünyası eleştirilir. Ayrıca metinde kaderci bakış açısı, eleştiriden nasibini alan bir diğer önemli unsurdur. Şair, talihinden şikâyetçidir. Bu şiirin içeriği; "Nasreddin Hoca’nın fikrasıyla”, "Şeyhî’nin Hârname” isimli eserini hatırlatır.

"Mademki olamadin bir dalkavuk maskara,

Karaya ak demedin, aka demedin kara,

Mademki oynamadin sen ele bir dubara,

Ümidin bağh kaldı elindeki bir zara,

Bekliyorsun şans eli bir düşeş atsın diye,

Ölme eşeğim ölme, yoncalar bitsin de ye.”(s.45-46)

Bursa'da 1938 yılında yazılan "Dam Üstünde Saksağan", kitapta yer alan on altıncı şiirdir. "Halk iken halkçı oldular", "Onlar bizden daha sağ, bizden daha soldular". "Yeter ki başımızda Ulu Önder să̆ olsun" gibi siyasi göndermelerde bulunulan şiirde politik kimliğini gizleyen, taraf değiştiren, kısa sürede zenginleşen, mal, mülk ve ün edinen, ikiyüzlü, fırsatçı eski tanıdıklar eleştirilir. Şair, bir yere gelemezken, çoğu arkadaşı milletvekili ve bakan olmuş, bazıları da ün ve nam kazanmıştır. Onun sitemi, bu tür insanların şaire daha sonra sırt çevirmesidir.

"Bütün eski tanışlar şimdi bize yâd oldu,

Kimisi saylav oldu, kimisi damat oldu,

Kimisi Şirin'leşti, kimisi Ferhat oldu,

Her birisi ülkede tanınmış bir ad oldu,

Bizler de iş edindik böyle destan yazmayl,

Dam ütünde saksağan vur beline kazmayı.”(s.47-48)

“Sizin ki Tatlı Can da” adlı şiir, kitabın on yedinci metnidir ve 1939'da Bursa'da kaleme alınmıştır. Eşitlik, adalet, hak gibi kavramların sorgulandığı şiirde, sosyal düzenin adaletsizliği eleştirilir. Şiir âdeta bir önceki metnin devamı gibidir. "Maroken koltuk"la bir önceki şiirde geçen "saylav (milletvekili)" kelimesine atıfta bulunulur. Ayrıca atıfta bulunulan diğer unsurlar, şairin kendi hayatı ve Lozan Antlaşması'dır. Metnin diğer önemli bir özelliği de baştan sona istifham/soru sorma sanatıyla oluşturulmuş olmasıdır.

"Ne sorulur bilseydik, amcamız, dayımız mı?

Değilse nemiz eksik aklımız, boyumuz mu?

Yoksa beğenilmiyen bir kötü huyumuz mu?

İmanımı mı bozuk, kanımı, soyumuz mu?

Bizim kanımız başka, sizinki başka kan mı?

Sizinki tath can da bizim ki pathcan mı?”(s.49-50)

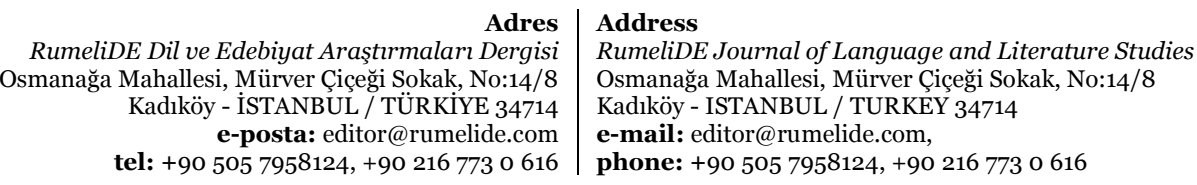


Devrin tek parti yönetimi CHP ve onun siyasi liderlerine göndermeler yapılan "Al Kaşağı Gir Ahıra" adlı on sekizinci şiirde; düzenin bozukluğu, yönetimdeki aksaklıklar, sosyal adaletsizlikler, dünyanın geçiciliği eleştirilir. Şiir, 1939 senesinde Bursa'da kaleme alınmıştır. Metinde "Beytullah, acun, bok" gibi farklı çağrışımlara kapı aralayan kelimelere de yer verilmiştir. Şiirde, paranın önemi vurgulanmış ve ona tapılması şiddetli şekilde tenkit edilmiştir. "Kazan kaldırmak" deyimiyle, Osmanlı Devleti zamanındaki yeniçerilerin ayaklanmasına telmihte bulunulmuştur. Yine "jurnalcilik" de bize II. Abdülhamit dönemini hatırlatan önemli bir sözcüktür. Bu yönüyle şiir, tarihi bir vesika niteliği taşır.

"Jurnalcılık, riyakârllk, geçer akça mal gibi,

Namusu da yemişlerdir çoklarımız bal gibi,

Kahbeliği bürünmüşler üstlerine şal gibi,

Bilâperva eğilirler her kuvvete dal gibi,

Sen milletin derdine yan, onlar kina yakınsin,

Al kaşağı, gir ahıra, yarası olan koçunsun." ${ }^{18}$ (s.51-52)

"Giden Ağam Gelen Paşam" isimli on dokuzuncu metinde bireysel çlkarlarını korumak, makammevkisini sağlama almak ve yarınını garantilemek için her şeye evet diyen, kişiye göre hareket eden insanlar eleştirilir. Şiir, 1939'da Bursa'da yazılmış ve "ne" kelimesi ilk bentte tam 7 defa tekrarlanarak kuvvetli bir musiki oluşturmuştur. Bu kelimeyle şair, âdeta şiddetli bir vurgu yaparak kendisini anlatmaya çalışmıştır.

"Ne evim var, ne postum var,

Ne düşmanum, ne dostum var,

Ne kimseye bir kasdim var,

Ne pabucum, ne mestim var,

İşte hırkam, işte asâm

Giden ağam, gelen paşam.

***

Yalnuz bizi soymuyorlar,

Hiç kimseyi kovmuyorlar,

Milyonlarla doymuyorlar,

Bağrışsak da duymuyorlar,

İşte sacım işte maşam,

Giden ağam, gelen paşam.” (s.53-54)

Bursa'da 1939'da yazllan "İki Gönül Bir Olunca” adlı şiir, kitapta yer bulan yirminci metindir. Şiirin bütününde bir kişiye kul olma, insandan medet umma, birinin emrine girerek rahat içinde yaşama ve iyi kulluk edenlerin başkan olması eleştirilir. Şiirde çok sayıda somutlaştırma örneği mevcuttur.

18 Mısradaki "koçunsun” kelimesinin doğru yazılışı "gocunsun”dur. Tahminimizce ya matbaa hatası ya da şairin kendisi konuşma dili olarak kullanmış olabilir.

RumeliDE Dil ve Edebiyat Araşttrmaları Dergisi Osmanağa Mahallesi, Mürver Ciçeği Sokak, No:14/8 Kadıköy - İSTANBUL / TÜRKIYE 34714 e-posta: editor@rumelide.com tel: +90 $5057958124,+902167730616$
Address

RumeliDE Journal of Language and Literature Studies

Osmanağa Mahallesi, Mürver Çiçeği Sokak, No:14/8

Kadıköy - ISTANBUL / TURKEY 34714

e-mail: editor@rumelide.com,

phone: +90 505 7958124, +90 2167730616 
"Dünyanın yasından sarhoş olup geçmek", "insanları dedikodu pasından meyin temizlemesi”, "efendinin nazartnın en büyük ihsan olması” gibi cümleleri buna örnek verebiliriz.

"Bir kapıya kul olurken benliği silmek gerek,

Efendinin dileğini lep demeden bilmek gerek,

Her nimeti, her hikmeti sözünde bulmak gerek,

Canla başla kul olursan efendin hayran olur,

İki gönül bir olunca, samanlık seyran olur."(s.55-56)

Kitapta yirmi birinci sırada yer alan ve Bursa'da 1939 senesinde yazılan önemli şiirlerden biri de, “Anlayana Sivrisinek Saz Gelir”dir. Bu dikkate değer metinde vurgulananlar şunlardır: Kimi zaman sözü biraz kapalı söylemek yeğlenir. Anlayışlı kimseler, ne denilmek istendiğini zaten anlarlar. Anlayışı kıt kimselere ise ne kadar açlk söylenirse söylensin, ne kadar tekrarlanırsa tekrarlansın yine de anlamayacakları ifade edilmiştir. Doğruyu anlamak her babayiğidin harcı değildir düsturu hâkimdir. Şiirde, insanın damgalı bir kula, talihin ise gözleri görmeden dönen bir ata benzetilmesi ilginçtir. Metinde insanoğlu, çeşitli hayvanlara benzetilerek sembolize edilmiştir.

"Talih atı gözleri görmez döner,

İğretiye binmiş olan tez iner,

Bir gece gökte nice yıldız söner,

Parlyyacak yıldızı bilmek hüner,

Karga uçarsa önüne baz gelir,

Anlyana sivri sinek saz gelir." (s.57-58)

"Pir Aşkına Hizmet" kitapta yirmi ikinci sırada yer bulmuş bir metindir. 1940 yllında Bursa'da yazılan son şiir olan ve dönemin işleyişine sitem edilen şiirde, asıl işi ve vazifeyi yapanların devletten ve milletten yardım alamadığını, bunun karşılı̆̆ında iş yapmadan çok kişinin her yerde ayrıcalıklı olduğunu vurgular. Kendisi gibi alçakgönüllü ve ne verirlerse onunla idare edenlerse devlete kayıtsız olarak hizmet etmeye devam eder. Şiirde, Tevfik Fikret’in ünlü şiiri "Hân-ı Yağma”ya atıfta bulunularak, şiirlerin yazıldığı her iki dönem birbirine benzetilmiştir. Şiirin içeriğinde askerî terimler (düzen, yurt, vatan, hizmet, gizli, emir, ganimet, alay, bölük, növbet vb.) ve divan edebiyatı unsurlarına (kûy-ı dildâr, bezm-i vuslat, gülşen, âşık-ı şeydâ, saf derûn, hâlet, teşne, kevser-i rahmet, ulviyet, bigâne, muhabbet, menzil vb.) yer verilmiştir.

"Hânı yağma"ya girenler şendi,

Her taraf onlara bir gülşendi,

Gizli bir emrile "Yağma" dendi,

Kuzular yendi, piliçler yendi,

Ellere türlü ganimet düştü,

Bize bir pir aşkına hizmet düştü.” (s.59-6o)

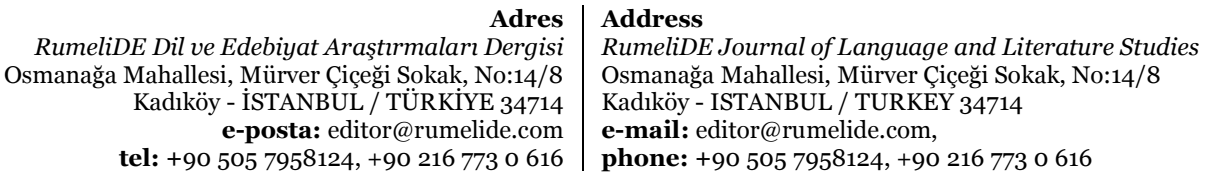


Kitabın yirmi üçüncü metni "Yaya Kaldın Tatar Ağası"dır. Şiir, 1942 yllında Ankara’da kaleme alınan ilk metindir. Şair burada kendisinin başarısızlı̆̆ına vurgu yaparak istediğini elde edemeyen, elindeki nice fırsatları kaçıran bir insanın ruh hâlini ifade etmiştir. Büyük davaların kalın kafalı insanlar tarafından yapıldığını, kendisinin ise onlardan zeki olduğu için içlerine alınmadığını anlatmaktadır. Burada, şairin Birinci Türk Dili Kurultayı'nda yaptığı muhteşem konuşmadan sonra Atatürk’ün dikkatini çektiğini, bu yüzden bazı kimseler tarafından bunun kıskanılarak İkinci Türk Dili Kurultayı'na özellikle davet edilmediğini düşünürsek, bu metnin neden yazıldığını daha iyi anlamış oluruz. Şiirde ayrıca tevekkül anlayışı da eleştiri oklarına maruz kalmıştır.

$$
\begin{aligned}
& \text { "İlim, sanat, mârifet hey, } \\
& \text { Vatan, millet, memleket hey, } \\
& \text { Nâmus, iman, hamiyet hey, } \\
& \text { Can ve gönülden hizmet hey, }
\end{aligned}
$$

\title{
Kalın kafanin dâvası,
}

Yaya kaldın tatar ağası!" (s.61-62)

Kitabın yirmi dördüncü şiiri önemlidir. Ankara'da 1942 yllında kaleme alınan “Yağma Hasan'ın Böreği”"19 adlı metinde; hakkı olanın da olmayanın da kolayca faydalandı $\breve{g} ı$, sahipsiz hiç kimsenin korumadığı mal mülk kaynağı, yani devlet malını yiyenlerin eleştirilmediği, yemeyenlerinse suçlandığının anlatıldığı görülür. Kısa yoldan zengin olmak isteyen köşe dönücüler, hak hukuk tanımazlar. Bunlar emek ve alın teri hırsızlarıdır. Şiirde bunlar eleştirilir. Metinde ayrıca, devlet malını yiyen insanlar, semiz bir hayvana benzetilmiştir. Burada yine Şeyhî’nin "Hârname" isimli eserini hatırlamak gerekir.

\section{"Devlet mah deniz derler, \\ Yemiyenler domuz derler, \\ Yiyen olur semiz derler, \\ Oraya ver omuz derler,}

\author{
Çekeceksin bu emeği, \\ Yağma Hasan’in böreği.” (s.63-64)
}

Ankara'da 1942 yılında kaleme alınan "Hancı Sarhoş, Yolcu Sarhoş" adlı şiir, kitaptaki yirmi beşinci metindir. Şiirde hem yöneticilerin hem de halkın sarhoşluğundan bahsedilir. Doğru söyleyenlerin kimse tarafından dinlenilmediği, değerli-değersiz şeylerin ayırt edilemediği ve ilmin ve sanatın ağır yara aldığı eleştirilir. Ayrıca hükûmet tarafından imtiyazlı sayılan adamların olduğu, bütün devletin imkânlarının sadece bunlara yâr olduğu vurgusu yapılmaktadır. Zekânın milletvekili koltuğundan

“Yağma Hasan’ın Böreği” deyimi: “Fatih’in Gebze'de ölümünden sonra (1481) İstanbul'da kıyamet kopmuş, zaten firsat bekleyen âsî yeniçeriler de İstanbul'a dağılmışlar. Kimse canından ve malından emin değilmiş. Yağmacı yeniçeriler, önce kendilerini aldatan sadrazam Karamanî Mehmet Paşa’yı parçalayıp konağını yağmalamışlar. Daha sonra şehirdeki zenginlerin konaklarına hücum edip her tarafı talan etmişler. Zengin Yahudilerin oturdukları semtlere akın eden zorbalar büyük yağmalar yapmışlar. Bu sırada Hasan adlı bir yeniçerinin işlettiği börekçi dükkânını da yağma eden yeniçeriler, işin aslını öğrenince, “Oldu bir kere, Yağma Hasan’ın böreğidir"diye, börekleri yemeye devam etmişler.” Bir diğer açıklama ise şöyledir: "2. Dünya Savaşı yıllarında, ekmeğin karneyle satılması firıncıları zora sokar. Bu sebeple çok sayıda firıncı, iș bırakır. İș bırakmayan Karaköy'deki börekçi Hasan ise beğenmediği börekleri sokağa döker. Kapışılan bu börekler, börekçi Hasan'ın, Yağma Hasan olarak anılmasına neden olur...” (https://www.egitimsistem.com/yagmahasanin-boregi-deyiminin-anlami-ve-kisaca-hikayesi-46725h.htm erişim tarihi: 18.03.2021.)

Adres | Address

RumeliDE Dil ve Edebiyat Araşttrmalar Dergisi $\quad$ RumeliDE Journal of Language and Literature Studies Osmanağa Mahallesi, Mürver Çiçeği Sokak, No:14/8 Osmanağa Mahallesi, Mürver Çiçeği Sokak, No:14/8

Kadıköy - İSTANBUL / TÜRKIYE 34714 Kadıköy - ISTANBUL / TURKEY 34714 e-posta: editor@rume tel: +90 505 7958124, +90 2167730616 phone: +90 505 7958124, +90 2167730616 
geldiği, deha sahibi olanların bu koltukta yükseldiği, servetin de fazilet anlamına geldiği ifade edilmiş; bütün bu olanların hoş görülmesine hikmet, alkışlamanın da siyaset olduğu anlatılmak istenmiştir. Akıllıca davranış metodunun susmak olduğu gözler önüne serilmiştir. Ayrıca şiirde "kadercilik" yani her şeyi olduğu gibi kabul etme ve "bana dokunmayan yılan bin yıl yaşasın" anlayışı eleştirilmiştir. Şiirin başlığı ve nakaratları bize Âşık Mahsunî Şerif in "Han sarhoş, hancı sarhoş./ Yolda yabancı sarhoş./ El çek tabip kalbimden/ İçimdeki sancı sarhoş” adlı kendi bestelediği şiirini hatırlatmaktadır. Muhtemeldir ki üstat Mahsunî Şerif, Namdar Rahmi’nin şiirlerinden haberdardır.

“Olanı hoş görüş hikmet,

Alkışlamak da siyâset,

Hiç üzülme, etme haset,

Susmak en büyük kiyâset,

Yum gözünü her taraf loş,

Hancı sarhoş, yolcu sarhoş.” (s.65-66)

Kitabın yirmi altıncı şiiri “Çıkmadık Canda Ümit Var” adlı metindir. 1943’te Ankara'da yazılan şiirde, en umutsuz olunan durumlarda dahi insanın ümidini yitirmemesi gerektiği, bazen umulmadık bir anda büyük dert ve acıların yerini sevinçlerin alabileceği vurgulanmıştır. İnsanlardan ümidini kesmemek gerektiği veciz bir şekilde dile getirilmiştir. Metnin içeriğinde bahta (talih) ve şansa (zar) çok yer verilmiştir. Şekilcilik bu metinde eleştiriden nasibini alan diğer bir davranış şeklidir.

"İsimiz hep bir zar işi,

Ona bağ hddr her kişi,

Ya atacaksın düşeşi,

Ya satacaksin geçmişi,

Bekle vakit olsa da dar,

Çıkmadık canda ümit var!” (s.67-68)

Kitapta yer alan yirmi yedinci şiir, İstanbul'da 1948 yılında yazılan "Su Testisi Su Yolunda Kırılır"dır. Bir kimse ya da şey, iyi ya da kötü hangi amaca hizmet ediyorsa o uğurda ölür ya da bir kazaya uğrar, yok olur düşüncesi manzumede sorgulanmaktadır. Metinde tezatlara fazlaca yer verilmiştir. "Ölmekdirilmek, kirli-duru, yaş-kuru, ak-kara" gibi zıt anlamlı kelimeler mevcuttur. Yine metinde şair, kendi memleketi olan Konya ağzında yer alan "harmanbişi" kelimesini kullanmıştır. Bu kelimenin anlamı; bir grupla oynanan bir toprak oyunudur. Şiirin önemli bir üslup özelliği de, bentlerden ikisinin tekrir, birinin tezat, birinin tenasüp ve diğerinin de benzetme sanatı ağırlıkta olduğu görülmektedir.

“Güvenilmez dostluğuna feleğin,

Düz ovada eteğine sarllır,

Kurtulursun güçlü ise bileğin,

Fakat kişi her gün ölür, dirilir,

En sonunda bir vargiya varllir,

Su testisi su yolunda krrllr."(s.69-70)

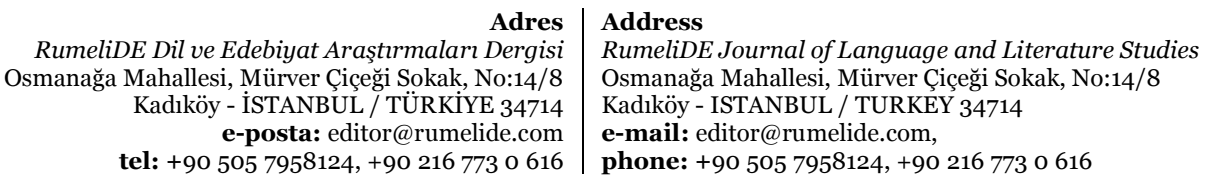


Kitapta yer bulan yirmi sekizinci şiir "Tezekten Terazinin” adlı metindir. Yazllış tarihi belirsiz olan bu şiirde, işlerin iyi gitmediği, adaletin olmadığı yerlerde doğru yapılan hiçbir şeyin olamayacağı vurgulanırken; ilimden sanata kadar pek çok unsur eleştiriden nasibini almıştır. Değersiz olarak kabul edilen şeylerin terazisi de yine ona nispetle değersiz olacaktır anlayışı hâkimdir. Bu şiirde, yeni şiirin (Garip/I. Yeni) eleştirilmesi, metnin 1940’tan sonra yazıldığını düşündürür. Kitapta tarih sırası gözetilerek metinler sıralandığı için, bize göre bu şiir de 1948-1949 yılları arasında kaleme alınmıştır. "Deveye neden böyle boynun eğik, demişler. Deve dudak bükerek, nerem doğru ki, demiş". "El elin eşeğini türkü çağırarak arar". "Kelin merhemi/ilacı olsa kendi başına sürer" gibi atasözlerinden metin içinde faydalanılmıştır. "Ol" kökünden türemiş kelimeler tam on dört kez tekrarlanırken, "böyle" dokuz, "bir" kelimesi de sekiz defa yinelenmiştir. Tüm bunlar şiirin muhtevasına uygun bir musiki ve ahengin sağlanmasını amaçlayan unsurlardır.

"Ele geçen firsatın hemen kavra belinden,

Çalş kütük kapmağa sen zamanin selinden,

Günün türküsü neyse o düşmesin dilinden,

Bahtın sana gülmezse hayr- umma el elinden,

Kendi başına sürer kelin olsa merhemi,

Tezekten terazinin b...tan olur dirhemi." (s.71-72)

Kitabın ilk baskısında yer almayan "Yıllık Destan" ikinci baskının son şiiridir. Namdar Rahmi’nin öğrencileri tarafından kitaba eklenmiştir. 1935-1936 yıllarında yaşanmış olayları anlatan bu destan, dönemin önemli vakalarını anlatması açısından âdeta tarihi bir belge niteliği taşır. Dönemin Bursa sosyal hayatından kesintilerin anlatıldığı, İstanbul'da büyük bir kasırganın olduğu, Dünya tarihinde, İtalya'nın Eritre'yi işgal ettiği haberlerini bu metinden alıyoruz. Ayrıca, dönemin memur ve öğretmenleri hakkında detaylı bilgiler de sunan destan, sosyal olaylar hakkında bilgilendirici olmanın yanında eleştirel ve kimi zaman da mizahi bir şiir olarak da dikkati çekmektedir. Bu destan, mektup halinde Çankırılı Tahsin Nâhid Uygur'a, şairin kendisi tarafından gönderilmiştir. Ayrıca şiir tarafımızdan, bir sempozyumda sunulmuş, kitap bölümü olarak da geniş tahlili yayımlanmıştır. ${ }^{20}$

"Mussolini kurt başııı kaldırd,

İtalya'yı Eritre'ye saldrtth,

Habeş elin asker ile doldurdu,

Göklere yükseldi feryâd-ı figân.

***

İstanbul'da müthiş firtına çıktı,

Hayli evler, damlar, köprüler yıkt,

Dediler: çok kimse canindan bıktı,

Olmamış tarihte böyle bir zaman.” (s.73-79)

2o Çandır, Kazım (2019), "Namdar Rahmi Karatay'dan Tahsin Nâhid Uygur’a Gönderilen "Yıllık Destan” İsimli Şiir Üzerinde Bir İnceleme”, Sosyal Bilimler İnsan Çalışmaları 2, Eğitim Bilimleri, Dil Bilimleri ve Felsefe Üzerine Güncel Tartışmalar, (Ed.) Zeynel Karacagil, Ali Osman Tiro, Ankara: Bilgin Kültür Sanat Yayınları, 16-31; (2019), "Namdar Rahmi Karatay'dan Tahsin Nâhid Uygur'a Gönderilen "Ylllı Destan” İsimli Şiir Üzerinde Bir İnceleme”, Uluslararası Multidisipliner Sosyal Bilimler Kongresi Bildiri Özetler Kitabı, 07-10 Mayıs 2019 Dil ve Tarih Coğrafya Fakültesi, Ankara/Türkiye, (Ed.) Prof. Dr. Salih Çeçen, Zeynel Karacagil, Ankara: Bilgin Kültür Sanat Yayınları, 205-206.

\section{Adres $\mid$ Address}

RumeliDE Dil ve Edebiyat Araşttrmaları Dergisi $\quad$ RumeliDE Journal of Language and Literature Studies Osmanağa Mahallesi, Mürver Çiçeği Sokak, No:14/8 Osmanağa Mahallesi, Mürver Çiçeği Sokak, No:14/8

Kadıköy - İSTANBUL / TÜRKIYE 34714 Kadıköy - ISTANBUL / TURKEY 34714 e-posta: editor@rumelide.com

e-mail: editor@rumelide.com,

tel: +90 505 7958124, +90 2167730616 phone: +90 505 7958124, +90 2167730616 
Kitapta yer alan şiirleri, ylllara ve mekâna göre değerlendirirsek şöyle bir sonuca ulaşlır. Şair, 1933, 1943 ve 1948'de birer, 1935, 1936, 1938 ve 1939'da dörder, 1937 ve 1942'de üçer, 1940'ta iki şiir kaleme almıştır. Tarihi belirsiz olan iki şiir kitapta yer bulmuş ve toplamda yirmi dokuz şiire ulaşılmıştır. Yayımlanan şiirlere mekân açısından da baktığımızda elimize şöyle bir veri geçer: Bursa'da yirmi üç, Ankara'da dört, İstanbul'da bir şiir yazılırken; bir şiirin nerede yazıldığı belirsizdir. Fakat biz, bu şiirin Bursa'da yazıldığını düşünüyoruz.

\section{3.Şiirlerin şekil, dil ve üslup yönünden incelenmesi}

\section{3-1. Şiirlerin şekil özellikleri}

Namdar Rahmi, incelememize örnek olan şiirlerini hece vezniyle kaleme almıştır. Zikredilen 29 şiirden on ikisi Türk şiirinde fazla kullanılmayan 14'lü hece vezniyle yazılmıştır. Bu vezinle yazılan şiirler şunlardır: "Geçti Bor’un Pazarı", "Poker Destanı", "Âşıklık Ne Halına...”, "Karaman’ın Koyunu...", "Çarşambadır Çarşamba...”, "Hani O Günler...”, "Eşeğe Gem Vurmayın...”, "Komşunun Tavuğu Kaz...”, "Ölme Eşeğim Ölme...”, "Dam Üstünde Saksağan...”, "Sizin ki Tatlı Can Da...”, “Tezekten Terazinin”.

Türk şiirinde çok kullanılan iki vezin olan 8 ve 11'li hece ölçüsüyle yazılan şiir sayısı toplam on bir adettir. Bunlardan altısı 8'li, beşi ise 11'li hece ölçüsüyle kaleme alınmıştır. "Harman Sonu Dervişlerin...", "Giden Ağam, Gelen Paşam...", "Yaya Kaldın Tatar Ağası...", "Yağma Hasan'ın Böreği...”, "Hancı Sarhoş, Yolcu Sarhoş...”, "Çıkmadık Canda Ümit Var...” adlı metinler 8'li hece ölçüsüyle kaleme alınırken; "Kırk Gün Taban Eti...”, "Leyleğin Ömrü...”, “Anlayana Sivrisinek Saz Gelir...", "Su Testisi Su Yolunda Kurllır...", "Yıllık Destan” isimli metinler ise 11'li hece ölçüsüyle yazılmıştır. Diğer şiirler 16’lı üç, 15’li iki ve 10’lu bir şiir, bu hece kalıplarıyla inşa edilmiştir. "İşte Geldik Gidiyoruz...", "Düşün Deli Gönül Düşün...”, "Sen Bir Garip Çingenesin...” 16’lı; "Al Kaşağı Gir Ahıra...”, “İki Gönül Bir Olunca...” 15’li; "Pir Aşkına Hizmet...” ise 10’lu hece ölçüsüyle yazılmış metinlerdir. Şair, zaman zaman mısraları vezne uydurmakta zorlansa da, çok başarılı bir hece şairi olduğunu söylememiz icap eder. Namdar Rahmi Karatay, 1933-1950 yılları arasında çok etkili olmuş, kendi dönemi ve sonraki kuşağı mizah şiirleri yönünden bir hayli etkilemiştir.

Nazım şekli ve nazım birimi yapısına bakıldığında şiirlerin daha çok $3^{+2}$ ve $4^{+2}$ dizeli yani beşlik (muhammes) ve altılık (müseddes tipi) ${ }^{21}$ bentlerle kaleme alındığı görülür. Şairin meramını en güzel şekilde dile getirdiği şiirler, bu nazım şekli ve birimleriyle yazılanlardır. Onun kaleme aldığı 29 şiirden on üçü $3+2$, on biri 4+2, dördü $(4+2$ ve $3+2)$ bentli karışık nazım şekliyle yazılırken, biri de "Ylllık Destan" olmak üzere dörtlüklerle ve destan nazım şekliyle inşa edilmiştir.

Beşlik bentlerle muhammes tipinde kaleme alınan şiirleri: "Geçti Bor'un Pazarı", "Poker Destanı", Âşıklık Ne Halına”, "Karaman’ın Koyunu”, "İşte Geldik Gidiyoruz”, "Çarşambadır Çarşamba”, "Düşün Deli Gönül Düşün...”, "Hani O Günler...”, "Sen Bir Garip Çingenesin”, "Leyleğin Ömrü”, "Eşeğe Gem Vurmayın”, “Harman Sonu Dervişlerin...”, "İki Gönül Bir Olunca...” adlı metinlerdir.

Altılı bentlerle müseddes şeklinde yazılanlar ise şunlardır: "Kırk Gün Taban Eti...”, "Komşunun Tavuğu Kaz...”, “Ölme Eşeğim Ölme...”, “Al Kaşağı Gir Ahıra...”, "Giden Ağam Gelen Paşam...”, "Pir Aşkına Hizmet...”, "Yağma Hasan'ın Böreğı”, "Hancı Sarhoş, Yolcu Sarhoş...”, “Çıkmadık Canda Ümit Var...”, "Su Testisi Su Yolunda Kırılır”, “Tezekten Terazinin...” isimli şiirlerdir. Karışık Düzenli hem

Muhammes ve müseddes nazım şekilleri için bakınız: Dilçin, Cem (1992), Örneklerle Türk Şïr Bilgisi, (2. Baskı), Ankara: Türk Dil Kurumu Yayınları, s.217-219, 227-230.

Adres | Address

RumeliDE Dil ve Edebiyat Araştırmaları Dergisi $\quad$ RumeliDE Journal of Language and Literature Studies Osmanağa Mahallesi, Mürver Çiçeği Sokak, No:14/8 Osmanağa Mahallesi, Mürver Çiçeği Sokak, No:14/8

Kadıköy - İSTANBUL / TÜRKIYE 34714 Kadıköy - ISTANBUL / TURKEY 34714 e-posta: editor@rumelide.com

e-mail: editor@rumelide.com

tel: +90 505 7958124, +90 2167730616 phone: +90 505 7958124, +90 2167730616 
muhammes hem de müseddes şeklinde yazılanlar: "Dam Üstünde Saksağan”, "Sizin ki Tatlı Can da...", “Anlayana Sivrisinek Saz Gelir...”, "Yaya Kaldın Tatar Ağası” metinleridir.

Şiirlerin kafiye sistemine baktığımızda, tam kafiyenin daha fazla kullanıldığını, bunun yanında zengin kafiyenin de bir hayli yer aldığını görüyoruz. Rediflere ise hemen hemen her manzumede rastladığımızı söylememiz gerekir. Her şiirin başlı̆̆ı da birer nakarat olarak metinlerde yer alır. Tüm bunlar şiirde musiki ve ritmi ayarlayan dış yapı unsurlarıdır. Şair, şiirinin müzikalitesini artırmak için bu tür yollara sıkça başvurur. Örnek olması bakımından bir şiirinin şekil bakımından tetkiki aşağıda verilmiştir:

Geçti Bor'un Pazarı

"Başta kavak yelleri estiği günler hani?

Umduğumuz neşeler, şerefler, ünler hani?

Beklenilen alayl, şanlı düğünler hani?

Selvi gibi ümitler döndü birer iğdeye,

Geçti Bor’un pazarı, sür eşeği Niğde’ye!

Sende cevher var imiş, onu herkes ne bilsin?

Kimler böyle züğürtün huzurunda eğilsin?

Şöyle bir dairede müdür bile değilsin,

Ne çıkar öğrenmişsin mesahası (piy) diye,

Geçti Bor’un pazarl, sür eşeği Niğde’ye!

Bilmem ki, ne olmaktı senin gâyen, maksadın?

Fare gibi kitaplar arasında yaşadın,

Ne dans ettin, eğlendin, ne de sevdin kız, kadın,

Kim dedi hey serseri gençliğine kıy diye?

Geçti Bor’un pazarı, sür eşeği Niğde’ye!

Gönül ne çalgı ister, ne eğlence, ne de dans,

Ne güzel kadınlarmn önlerinde reverans,

Kapandıkça kapandı bunca yıldır kahpe şans,

İhtiyarlkk gölgesi perde çekti dîdeye,

Geçti Bor’un pazarı, sür eşeği Niğde’ye!

Firsat iyi kolla, olma sakn dangalak,

Genç iken vur partiyi, durma, ye, keyfine bak,

Sonra iç şampanyalar, viskiler, bardak bardak,

RumeliDE Dil ve Edebiyat Araştırmaları Dergisi Osmanağa Mahallesi, Mürver Çiçeği Sokak, No:14/8 Kadıköy - İSTANBUL / TÜRKIYE 34714 e-posta: editor@rumelide.com tel: +90 $5057958124,+902167730616$
Address

RumeliDE Journal of Language and Literature Studies

Osmanağa Mahallesi, Mürver Çiçeği Sokak, No:14/8

Kadıköy - ISTANBUL / TURKEY 34714

e-mail: editor@rumelide.com,

phone: +90 505 7958124, +90 2167730616 
Dokunuyor üç kadeh şimdi bizim mideye,

Geçti Bor’un pazarı, sür eşeği Niğde’ye!

Hasan'in böreğine vaktinde yetişmeli,

Hiç durmadan gövdeye atıştırıp şişmeli,

Yanıp da kavrulmadan mükemmelen pişmeli,

Sonra seni almazlar hiçbir yere çiy diye,

Geçti Bor'un pazarı, sür eşeği Niğde'ye!”

Bursa- 1933 (s.17-18.)

Bu metin, hem şairin hem de kitabın en ünlü şiiri konumundadır. 14'lü hece ölçüsüyle yazılan şiirin durakları da 7+7 şeklindedir. Her bendi beşliklerden oluşan şiir, 3+2'lik düzenden oluşur. Muhammes tipinde yazılmış bir şiirdir. Şiirin adı aynı zamanda nakarat mısraında da tekrarlanır ve musiki yapısına katkıda bulunur. Metnin kafiye yapısı şöyledir: 1. Bent: -ler hani: redif, -ün: tam kafiye, -ye: redif, -iğde: zengin ve aynı zamanda bir tunç kafiye örneğidir. 2. Bent: -sin: redif, -il ve -ye: tam kafiyedir. 3. Bent: -adın: zengin kafiye, -ye: tam kafiyedir. 4. Bent: -ans: zengin kafiye, -ye: redif, -de: tam kafiyedir. 5. Bent: -ak ve -de: tam kafiye, -ye: rediftir. 6. Bent: -meli: redif, -iş ve -ye: tam kafiyedir.

Yukardaki kafiyelere baktığımızda tam kafiye ağırlıklı olduğu, hemen hemen her bentte redife yer verildiği görülür. Zengin kafiye daha azdır. Yarım kafiyeye burada hiç rastlanmaz. Fakat şairin diğer şiirlerinde yarım kafiyeyi nadir de olsa kullandığı görülür. Şiirin kafiye örgüsü de şu şekildedir: aaa $\mathrm{bb} / \mathrm{ccc} \mathrm{bb} / \mathrm{ççç} \mathrm{bb/ddd} \mathrm{bb/eee} \mathrm{bb/fff} \mathrm{bb.} \mathrm{Bu} \mathrm{tür} \mathrm{kafiye} \mathrm{örgüsü} \mathrm{muhammes} \mathrm{tipinde} \mathrm{yazılan} \mathrm{diğer} \mathrm{şiirlerin}$ on ikisinde de aynıdır. Müseddes tipi kafiye örgüsü ise şöyledir: aaaa bb/cccc bb/çççç bb/dddd bb/eeee bb/ffff bb. Karışık düzenliler de bu iki tipin örgüsüyle oluşturulmuştur. Destan tarzıyla yazılan tek şiir olan "Ylllık Destan”ın kafiye örgüsü: abab/ cccb/ çççb / dddb/ eeeb/ fffb/ gggb/ hhhb/ 111b/ iiib/ ... şeklinde kırk beş dörtlük devam etmektedir.

\section{2. Şiirlerin dil ve üslup özellikleri}

Kitapta yer alan tüm şiirleri dil yönünden ele aldığımızda, şairin dilinin sade, anlaşlır ve halkın hoşlanacağı akıcı bir dil olduğu görülür. Şairin dil ve üslubunu orijinalleştiren önemli unsurlar vardır. Bunlar, başta deyimler olmak üzere, atasözü, halk ağzı deyişler, ikilemeler ve pekiştirmelerdir. Türkçenin söz varlığı içinde yer alan bu tür kelime ve ibareler, benzetmeye ve nükteye olan eğilimi de ifade eden önemli unsurlardır. "Bir dilin sözvarlığı içinde yer alan atasözleri bir toplumun bilgeliğini, deneyimlerini, dünya görüşünü ve anlatım gücünü yansıtan, yüzyllarca yaşayabilen sözlerdir.” (Aksan, 1996: 33). Şair de yaşadığı toplumun içinden çıan bir birey olarak, yazdığı metinlerde, Türkçe'nin gücü hâline gelmiş bu öğelerden faydalanacaktır. Her şiirin başlığını da buna benzer bir söz grubu oluşturur. Aşağıya vereceğimiz örnekler bize somut olarak bu gerçeği gösterir:

\section{Şiirlerdeki deyimler ve birleșik fiiller}

“(Bir şeye) kul olmak/(Birine) kul köle olmak. (Bir şeye) kulak(larını) tıkamak. (Bir şeyin) yolunu tutmak. (Biri, birine) deli divane âşık olmak. (Birinden, bir şeyden) ağzı yanmak. (Birine) kucak

\footnotetext{
RumeliDE Dil ve Edebiyat Araştırmaları Dergisi Osmanağa Mahallesi, Mürver Ciçeği Sokak, No:14/8 Kadıköy - İSTANBUL / TÜRKIYE 34714 e-posta: editor@rumelide.com

Address

RumeliDE Journal of Language and Literature Studies

Osmanağa Mahallesi, Mürver Çiçeği Sokak, No:14/8

Kadıköy - ISTANBUL / TURKEY 34714

e-mail: editor@rumelide.com,

tel: +90 505 7958124, +902167730616 phone: +90 505 7958124, +90 2167730616
} 
(kucağını) açmak. (Birini) tefe koymak. (Birinin) başına çorap örmek. (Birinin) kuyusunu kazmak. (Bir şeyin) iç yüzü. (Her şeye) baş sallamak. Ağzı açık kalmak. Ahkâm çıkarmak. Akı kara, karayı ak göstermek. Akıntıya (akıntıya karşı) kürek çekmek. Akıntıya kapılmak. Akla karayı seçmek. Aklını yitirmek. Alnı açık, yüzü ak (olmak). Altını üstüne getirmek. Apar topar (gitmek). Arı gibi çalışmak. Aslan payı. Atı alan Üsküdar’ı geçti. Bağrına taş basmak. Bahtına küsmek. Baldırı çıplak. Başa kakmak. Başına devlet (talih) kuşu konmak. Başına taç etmek. Başında kavak yelleri esmek. Bir işe girişmek. Bir lokma bir hırka. Biti kanlanmak. Boğaz tokluğuna çalışmak. Borusu ötmek. Boynu bükük (kalmak). Bozuk para gibi harcamak/(pul gibi harcanmak). Bulanık suda balık avlamak. Can (canını) sıkmak. Canından bezmek (bıkmak veya usanmak). Cefa çekmek (görmek). Ciğeri yanmak. Çağı geçmek. Çalım satmak. Çile çıkarmak (doldurmak). Dalkavukluk yapmak/etmek. Defterini dürmek. Derdine yanmak. Dik kafalı (olmak). Dimyat'a pirince giderken evdeki bulgurdan olmak. Dört bir yana dağılmak (koşmak). Duman almak (sis kaplamak). Durumdan vazife çıkarmak. Dünyadan el etek (elini eteğini) çekmek. Düzen vermek (düzene girmek). Ecel şerbeti içmek. Eline eteğine sarılmak/Eteğine düşmek (sarılmak). Emek çekmek. Eski hamam eski tas. Etliye sütlüye karışmamak. Fırtına çı(ar)mak. Gelip geçmek. Gemi azıya almak. Gezip tozmak. Gönlünde (gönüllerde) taht kurmak. Göz boyamak. Göz koymak. Gözleri kan çanağına dönmek (kanlanmak). Gözünü (gözlerini) (bir şeye) dikmek. Gözünü (gözlerini) açmak. Gözünü (gözlerini) kapamak. Gül gibi geçinmek/(yaşamak). Güneş doğmak. Haber almak. Haddini bilmek. Halt etmek. Hapı yutmak. Havanda su dövmek. Hayır dua etmek. Hesap sormak. Hiçe saymak (indirgemek). Hoş görmek. İçin için yanmak (içinden yanmak). İpe un sermek. Kafa tutmak. Kanı bozuk. Kanı donmak (çekilmek). Karda yürüyüp (gezip) izini belli etmemek. Kazan kaldırmak (devirmek). Kelepçe vurmak (takmak). Kendini tartmak. Keyfine bakmak. Keyif çatmak. Kına (kınalar) yakmak (koymak, sürmek, vurmak, yakınmak, yakılmak). Kısmeti kapanmak. Kof çlkmak. Köşe bucak saklanmak (pineklemek). Kul olmak. Kulak vermek. Kurban vermek. Kurbanlık koyun gibi. Laf söyledi bal kabağı! Lânet okumak. Lâyık görmek. Leb demeden leblebiyi anlamak. Maruz kalmak. Maskara olmak. Medet ummak/(iyilik ummak). Meyil vermek. Mezarını kazmak. Modası geçmek. Nabza göre şerbet vermek. Omuz vermek. Ortaya çıkarmak. Oyuncak olmak. Ölüp ölüp dirilmek. Ömür Geçirmek. Pamuk gibi (olmak). Parmağını bile kıpırdatmamak (oynatmamak). Perişan olmak. Pir aşkına. Pişmiş aşa su katmak. Postu sermek. Pusuya yatmak. Saltanat sürmek. Sefa sürmek/sefasını sürmek. Senin ki can da benim ki patlıcan mi. Sinirleri gerilmek. Sonu gelmek. Sütliman olmak. Şaka gibi gelmek. Şapa oturmak. Şapka çıkarmak. Tadını çıkarmak. Tam takır kuru bakır. Tezekten terazinin boktan olur dirhemi. Turnayı gözünden vurmak. Ucu (herhangi birine) dokunmak. Ulu orta söz söylemek. Umudunu kesmek. Uyuz olmak. Uzaktan bakmak (seyirci kalmak). Ün almak (kazanmak, salmak, yapmak). Vız gelmek. Yaka silkmek. Yara açmak. Yarışa girmek. Yaya kaldın tatar ağası. Yaya kalmak. Yolu açı olmak. Yurt edinmek (tutmak). Yükünü çekmek. Yüreğinin yağı (yağları) erimek. Yüzüne gülmek. Zülfü yâre dokunmak.”

\section{Atasözleri}

"Al kaşağıyı gir ahıra. Âlem yine ol âlem, devran yine ol devran. Anlayana sivrisinek saz, anlamayana davul zurna az (gelir). Armudun iyisini (irisini) ayılar yer. Çıkmadık candan ümit kesilmez. Dam üstünde saksağan, vur beline kazmayı. Demir tavında dövülür. Deveye "boynun eğri" demişler; "nerem doğru ki? ” demiş. Devletin malı deniz, yemeyen domuz. Durdu durdu, turnayı gözünden vurdu. Eğreti ata (el atına) binen tez iner. El elin eşeğini türkü çağırarak arar (el elinden hayır umma). Gelen ağam giden paşam. Gidip de gelmemek var, gelip de görmemek (bulmamak) var. Hancı sarhoş yolcu sarhoş. Her güzelin bir kusuru vardır. Her yokuşun bir inişi, her inişin bir yokuşu vardır. İki gönül bir olunca samanlık seyran olur. Kara haber tez duyulur. Karaman'ın koyunu sonra çıkar oyunu. Kelin merhemi olsa başına sürer. Kimse bilmez, kim kazana kim yiye. Leyleğin ömrü (günü) laklakla geçer. Ölme

\footnotetext{
Adres $\mid$ Address

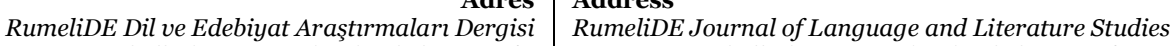
Osmanağa Mahallesi, Mürver Çiçeği Sokak, No:14/8 Osmanağa Mahallesi, Mürver Çiçeği Sokak, No:14/8 Kadıköy - İSTANBUL / TÜRKIYE 34714 Kadıköy - ISTANBUL / TURKEY 34714 e-posta: editor@rumelide.com e-mail: editor@rumelide.com tel: +90 505 7958124, +90 2167730616 phone: +90 505 7958124, +90 2167730616
} 
eşeğim, ölme (yaza yonca bitecek). Su testisi su yolunda kırılır. Yarası (yağırı) olan gocunur (gocunsun). Zengin arabasını dağdan aşırır, fakir düz ovada yolunu şaşırır. Zügüüt olup düşmektense uyuz olup kaşınmak yeğdir.”

\section{İkilemeler ve pekiştirmeler}

"Ak ak. Akı karayı seçmek. Apar topar. Bağır çağır. Baka baka. Bardak bardak. Baştan başa. Birer birer. Bol bol. Bomboş. Çapituna çuluna. Çarşambadır Çarşamba. Dağdan dağa. Dan dan. Dedi kodu. Derin derin. Diye diye. Durur durur. Duyar duymaz. El âlem. El etek çekmek. Etliye sütlüye karışmamak. Gece gündüz. Geçip gitmek. Gezip tozmak. Gidip gelmemek, gelip bulmamak. Gün gün. Hısım akraba. Hinoğlu hin. Kana kana. Kapandıkça kapandı. Kara kara. Karaya ak/aka kara. Karayı ak göstermek. Karma karışık. Kat kat. Kıpkızıl. Köşe bucak. Oğlandır oğlan. Para pul. Perde perde. Perşembedir Perşembe. Salına salına. Tam takır. Taştan taşa. Uma uma. Uzun uzun. Üçün beşin. Yemyeşil olmak. Yılan çıyan.”

Şairin önemli bir yönü de halk ağzı kelimelere çokça yer vermesidir. Mesela Konya'da çocuklar arasında oynanan "harmanbişi” bunlardan biridir. Bundan başka çok sayıda halk ağzı örnekleri vardır. İşte onlar:

"Yayan kalmak, dangalak, partiyi vurmak, yulak, çapit, çul, uma uma, şapa oturmak, tefe koymak, eloğlu, hinoğlu hin, ibiş, etliye sütlüye karışmamak, kursak, bulamaç, kaltaban, buyruk kulu, batakta köprü olmak, kıl kuyruk, çalım satmak, kafa tutmak, aşa ağı katmak, boğaz tokluğu, alık, siyasa, bellemek (öğrenmek), aba, umuda salmak, tamu, bitek (verimli), kendini tart, yokla peşin, halt etmek, uyuz, iş işlemek, yaka silkmek, tınmamak, gönüllerden eteği çekmek, şakşakçı, tuzakçı, tavcı, yavru baz, göz bă̆ıcı, gözleri sürmeli hacılar, taban eti, yürünmek, iki gözüm, nene gerek, topal eşek, çingene, telli zurna, ille, yürek üzmek, açıgöz, medek, zati (zaten), sırmalı don, takım dârât, cepken, yamalı mintan, bezenmek, kurulmak (övünmek), hısım, kavim, bol bol serilmek (güç sahibi olmak), kabak, kelek, laklak, koruk, şakşak, vakvak, tüze, humma, ele alçak durmak, pehpeh, pohpoh, it (insanlar için kullanılır), saltanat yapmak, çul, kalafat, hamal kayığı, harman sonu, dizginsiz gidiş, marsık, kıraç, kuru, cılız, yavuz, kel, şerbet, ayran, kımız, karışık iş, hapı yutturmak, şafak atmak, çiyan, sona yetmek, dalkavuk, maskara, dubara, eski tanışlar (dost, tanıdık, ahbap), saylav (milletvekili), apartıman, semizlenmek, kanlanmak, bostan, azmak, güzelin evcili, fikırdak kadın, yosma, civan, kayrılmak (atanmak, makam vermek), doğrulmak, eğrilmek, divanda encümen de kurulmak (yer almak), yorulmak (çalışmak, iş yapmak), insan sırasında görülmek, posteki, el âlem, yolunmak, sorguç takınmak, yarası olan koçunsun/gocunsun, kaşă̆ı, aygır, tosun, kahbe, kına yakınmak, bok, ifrit, lüfer diye sazanı yutturmak, kazan kaldırmak, dönek acun, pabuç, mest, hırka, post, asa, kemlik görmek, başa çorap örmek, defterini dürmek, dedikodu pası, kaynaşmak, Âdem baba, beylik, efendilik, katra (katre), doğru yolu keşfetmek, toy, vız gelmek, yoz gelmek, pul gibi harcanmak, gül gibi yaşamak, girdisi çıktısı var, ömrünü harcanma (hayatını vermek), salta, iğreti, baz, gönül bezeme (süslemek), pinti, boynu bükük derbeder, növbet, hâlet, pineklemek, odlara yanmak, muhtara çatmak, kalın kafanın davası, tam takır kalmak, salgın salmak, şilte, para dökmek, elin maskara köpeği, kör döğüşü, köftehor, çiftetelli oynamak, sırtı yağır olmak, habire koşmak, kudurmak, delirmek, floş, uşak (insanlar), geçmişi satmak, külâhı kapmak, yapıntı, baldırı çıplak, vargıya varmak (sonuca ulaşmak), parti pırtı, tezek, dirhem, koşumu çözük olmak, keseye kazık olmak, geçimi hedef etmek, düşkün sürü, kof, püf, cümbüş, fırsatın belinden kavramak, kütük kapmağa çalışmak, zamanın seli, günün türküsünü dilden düşürmemek, tıkınmak, yutkunmak, başa kakmak, soysuzun keremi, halt yapmak, vukuat, ecel şerbetini nûş etmek, duhan (tütün, sigara), komamak (koymamak), Fesuphan,

\footnotetext{
\begin{tabular}{r|l} 
Adres & Address \\
RumeliDE Dil ve Edebiyat Araşttrmaları Dergisi & RumeliDE Journal of Language and Literature Studies
\end{tabular} Osmanağa Mahallesi, Mürver Çiçeği Sokak, No:14/8 Osmanağa Mahallesi, Mürver Çiçeği Sokak, No:14/8 Kadıköy - İSTANBUL / TÜRKIYE 34714 Kadıköy - ISTANBUL / TURKEY 34714 e-posta: editor@rumelide.com e-mail: editor@rumelide.com, tel: +90 505 7958124, +90 2167730616 phone: +90 505 7958124, +90 2167730616
} 
cümleten, dan dan, nazara inanmak, havadis, ehli salib, sür sal etmek (saldırmak), zemheri, piyasa, istihraç, hasılıkelam, harp, Alamanlar, mister, birader, temiz oğlan (Tahsin Nahit Uygur için), kavut.”

Bunların yanında vurgunun sağlandığı tekrarlar, manzumelere ayrı bir güzellik ve akıcılık kazandırır. Bunlar hakkındaki örneklere edebî sanatlarda yer vereceğimiz için, burada değinip geçiyoruz.

\section{Edebî sanatlar}

Edebî sanatlara şiirlerinde bolca yer veren şair, özellikle tezat, benzetme/teşbih, teşhis sanatını manzumelerin ana unsuru hâline getirir. İstiare, mecaz-ı mürsel, nida, tekrir, tenasüp, tecahül-i ârif, istifham ve telmih diğer kullanılan edebî sanat türleridir. Üslubun önemli unsurlarından biri olan bu sanatlar, ifadeye güzellik kattığı gibi, aynı zamanda kelimelerin çă̆rışım gücünü de artırıcı bir rol oynar. Kitaptaki her şiirde çok sayıda edebî sanat örneklerine rastlanır. Aşağıya önemli gördüklerimizi almakla iktifa edeceğiz.

\section{Teşbih/benzetme}

“Servi gibi ümitler döndü birer iğdeye, (Şair, ümitlerini serviye ve iğde ağacına benzetmiştir).” "Fare gibi kitaplar arasında yaşadın, (Şair, kendisini fareye benzetir)." Kapandıkça kapandı bunca yıldır kahpe şans, (Şair, kapanan şansını bir kahpeye benzetmiş)." Keşiş̌in eteğinde yaşadım keşiş gibi,/Bir lokma, bir hrkkaya hu' diyen derviş gibi, (Şair, kendisini hem keşişe hem de dervişe benzetmiştir)." "Harcadım hayatımı beş paralık fiş gibi. (Şair, burada kendi hayatını kumar fişlerine benzetir)."

\section{Tezat/zitlık}

"Ne dişisine inan, ne erkeğine kan, (dişi-erkek: tezat)." "Bir gölgeye benzer umut, bir uzanır, bir kısalır, (uzamak-kısalmak tezat)." "Cennet köşkündeyiz, de, olsak bile tamuda, (cennet-cehennem (tamu) tezat)." "Geceler çift doğurur, şimdi gündüzler gebe, (gece-gündüz tezat)." "Eski putlar yıkıldı, yenilere tapıldl, (eski-yeni tezat)./Herkes geceler gündüz oldu diye kapıld,, (gece gündüz: tezat).” "Bugünkü kara kara, bugünkü ak ak mıydı? (kara-ak: tezat )." "Âlemde ne kadar çok baylar var, bayanlar var. (baylar-bayanlar tezat)." "Girdisi var çıktısı var aman, (girdi-çıktı tezat)." "Hiç farketmez kirlimizle durumuz,/Geçecektir hep yaşımız, kurumuz,/Kırmızımız, akımızla, karamız, (kirli-duru, yaş-kuru ve ak-kara tezat).”

\section{Teşhis/kişileştirme}

"Düşün deli gönül düşün, adam eşek mi alır kışın! ("gönül” kişileştirilmiştir)." "Fazilete, vefâya, aşka kandığın günler? ("fazilet, vefa ve aşk kişileştirilmiştir)." "Nasıl söyler bu sözü bayramı gören matem, ("matem” kişileştirilmiştir)." "Sanmayın gönüllerden eteği çekti elem, ("elem” kişileştirilmiştir)." "Geceler çift doğurur, şimdi gündüzler gebe, (gece ve gündüz kişileştirilmiştir)." "Kapandıkça kapandı bunca yıldır kahpe şans, (şans kişileştirilmiştir).”

\section{İstiare/eğretileme}

"Kimler böyle züğürdün huzurunda eğilsin, (Züğürt kelimesinde istiare sanatı vardır)." "Senin her gün bir kambur yüklenirken dalına, (şair burada kendisini ağaç dalına benzetmiş. İstiare yapmıştır. Çektiği sıkıntı ve dertleri de kambura benzetmiştir.)" "Eloğlunu bilmezsin, o ne hinoğlu hindir, (eloğlu: rakipler anlamında ve hinoğlu hine benzetir)." “Sana ölçü verirler uzatırsan boynunu, (ölçü

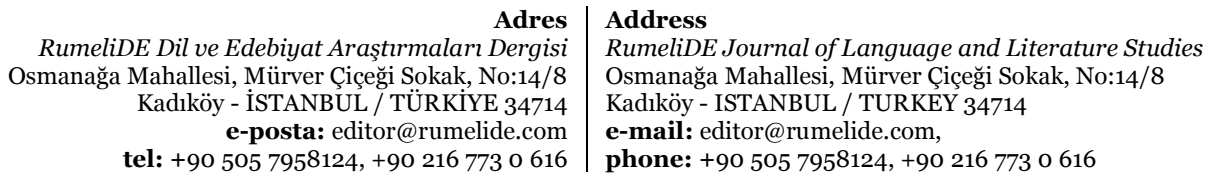


vermek: istiare)." "Bir kılkuyruk gelir sana çalım satar, kafa tutar, (kılkuyruk: istiare)." "Açıkgözler yakalamış her biri bir ball petek, (açıkgözler: istiare)."

\section{Mecaz-ı Mürsel}

"Dinlenmeden bir gün başım gençlik böyle geldi geçti, (gençlik, mecaz-ı mürsel, parça-bütün ilişkisi)." "Baş sallamayı öğren, büyük önünde eğil, /Sallanır şapkayla da baş hep kavukla değil, /Eski kavuklar şapka, fraklar eski aba, (baş sallama, eğilme, şapka, kavuk, fraklar, aba: mecaz-ı mürsel)." "Unuttular yollarda yaya gezip tozmayı, (yaya kelimesi mecaz-ı mürsel)."

\section{Nida/seslenme}

"Ne beklerdin, ne buldun sen yeryüzünde hey serseri?/ Ey hakikat sen ki bana el âlemden yakinsin./ Niçin seni yolsunlar da eller sorguç takınsın?/ Ey dünya sen ne maskara, ne dönek bir acunsun? İlim, sanat, marifet hey, /Vatan, millet, memleket hey, /Namus, iman, hamiyet, hey, /Can ve gönülden hizmet hey, /Kalın kafanın davası, /Yaya kaldın tatar ă̆ası!”

\section{Tekrir/yineleme}

"Gönül ne çalgı ister, ne eğlence, ne de dans, ("ne"ler tekrir sanatı)." "Gönül sen ne sersemsin, ne körsün, ne sakarsın, (ne...ne :tekrir sanatı)." "Karardıkça karardı kara baht kurum gibi, (Bu mısrada kara sözleriyle başlayan kelimelerde tekrir sanatı vardır)." "Çarşambadır çarşamba, perşembedir perşembe. (Çarşamba ve Perşembe tekrarlanmıştır.)" "Yeni güneşler doğdu, yeni mâbet yapıldı, ("yeni" kelimeleriyle tekrir yapılmıştır)." "Güneş yine o güneş, ışık yine o ışık, ("güneş ve ışık" kelimeleriyle tekrir sanatı yapılmıştır)." "Devran yine o devran, âlem yine o âlem. ("devran ve âlem" kelimelerinde tekrir sanatı vardır)." "Varsin onlar bezensinler, varsin onlar kurulsunlar, /Varsin bütün hısım kavim birbirine sarılsınlar, (varsın kelimesinde tekrir sanatı vardır.)"

\section{Tenasüp/uygunluk}

"Kar yağar, güneş açar, uğurlu yeller eser, (kar, güneş, yel arasında tenasüp var.)" "Canın keklik ister, ördek vurursun, /Bıldircm sanırsin, leylek vurursun, (keklik-ördek-bıldırcın-leylek kelimelerinde tenasüp sanatı vardır.)" "Gül ile sümbül ile zambak ile, (gül, sümbül, zambak arasında tenasüp vardır.)" "Kol, kanad, kelle ve boynuz, kuyruk, (tüm kelimeler arasında tenasüp vardır.)" "Otomobiller var, athlar, yayanlar var, (otomobil, atlı, yaya/yayan arasında tenasüp vardır.)"

\section{Tecahül-i ârif/bilmezlikten gelme}

"Bu âlem mi değişti, ben mi değiştim bilmem?" "Bilmem ki nasıl yazmış bunu keskin bir kalem?" “Kırk yıl posteki gibi sürünen de insan mı?”(Mısralarında tecâhül-i ârif sanatı vardır.)

\section{İstifham/soru sorma}

"Balı, kaymağı sizin, bize acı soğan mı?/ Sizinki tatlı can da bizim ki patlıcan mı? /Başta kavak yelleri estiği günler hani? /Umduğumuz neşeler, şerefler, ünler hani? /Beklenilen alayl, şanl düğünler hani? /Sende cevher var imiş, onu herkes ne bilsin? /Kimler böyle züğürtün huzurunda eğilsin? /Bilmem ki, ne olmaktı senin gayen, maksadın? /Kim dedi hey serseri gençliğine kıy diye?

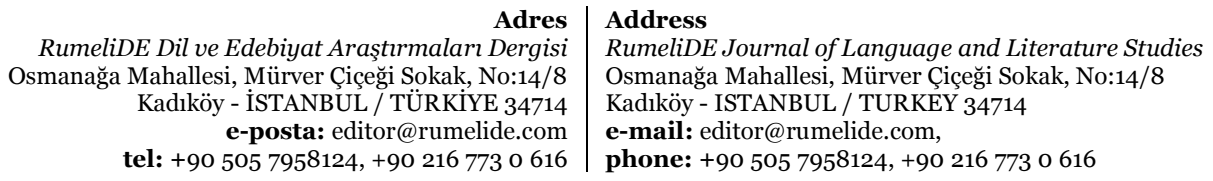


/Ne beklerdin, ne buldun sen yeryüzünde hey serseri? /Bilinir mi böyle yerde bir kimsenin öz değeri? /Böyle bitek tarladan umudunu kim keser?” (Mısralarında istifham sanatı vardır.)

\section{Telmih/hatırlatma}

"Çünkü senin tahtında o zaman hakandı Cem, (Cem'e telmih yapılmıştır.)" "Kimisi Şirin'leşti, kimisi Ferhat oldu, (Şirin ve Ferhat'a telmih yapılmıştır.)" "Yeter ki başımızda Ulu Önder să̆ olsun, (Atatürk'e telmih yapılmıştır.)" "Emretseler yakacağız, Beytullah’ı yak diye (Kâbe'ye telmih.)" "Biz de Âdem babamızı bir günahkâr kuluyuz, (Hz. Âdem'e telmih.)" "“Hâm yağma”ya girenler şendi/ Her taraf onlara bir gülşendi, (Tevfik Fikret’in "Hân-ı yağma" şiirine telmih.)" Eyüp sabrı bu olacak, (Hz. Eyyub’a telmih.)” “Böyle uyuz Asl'nın kambur olur Kerem’i (Aslı ile Kerem'e telmih.)”

\section{Sonuç}

Cumhuriyet döneminin önemli hiciv şairlerinden biri de Namdar Rahmi Karatay'dır. Onun bu tür şiirlerini topladığı eseri, “Geçti Bor’un Pazarı"dır. Şiirlerin temalarına baktığımızda, şairin devrinde pek mutlu olmadığını, hemen hemen her şeyden şikâyet ettiğini görüyoruz. Şairin başından geçen kötü olaylar, kendi yakın çevresinden ve arkadaşlarından gördüğü döneklik, kaypaklık, kıskançlık ve ikiyüzlülük metinlerin ana temasını oluşturur. Tüm şiirler Namdar Rahmi'nin "hayal-hakikat" çatışması ekseninde kaleme alınmış ancak $\mathrm{O}$, her zaman hayatın gerçeğinden darbeleri yemiştir. Kısaca söylemek gerekirse; şairin hiçbir hayali, maalesef yaşarken de vefatından sonra da gerçekleşmemiştir.

Namdar Rahmi, incelememize örnek olan şiirlerini hece vezniyle kaleme almıştır. Zikredilen 29 şiirden on ikisi, Türk şiirinde fazla kullanılmayan 14'lü hece vezniyle yazılmıştır. Türk şiirinde çok kullanılan iki vezin olan 8 ve 11'li hece ölçüsüyle yazılan şiir sayısı, toplam on bir adettir. Bunlardan altısı 8'li, beşi ise 11'li ölçüyle kaleme alınmıştır. Diğer şiirlerden üçü $16^{\prime}$ lı, ikisi $15^{\prime}$ 'li ve biri de 10'lu hece kalıplarıyla inşa edilmiştir. Şiirlerin nazım şekilleri; muhammes, müseddes, bu iki türden oluşan karışık bentli ve destan tarzından oluşur. Nazım birimi yapısına bakıldığında şiirlerin daha çok $3+2$, 4+2 yani beşlik ve altılık bentlerle kaleme alındığı görülür. Şairin meramını en güzel şekilde dile getirdiği şiirler bu nazım birimleriyle yazılanlardır. Şairin kaleme aldığı 29 şiirden on üçü, 3+2; on biri, 4+2, dördü, her iki bendin karışımından ve biri de -Yıllık Destan olmak üzere- 4'lüklerden oluşmuştur. Şiirlerin kafiye sistemine baktığımızda, tam kafiyenin daha fazla kullanıldığını, bunun yanında zengin kafiyenin de bir hayli yer aldığını görüyoruz. Rediflere ise hemen hemen her manzumede rastlanır. Şiirlerin ses ahengini ve musikisini sağlayan çok sayıda unsur vardır. Özellikle her şiirin başlığını da oluşturan nakaratlar, bunların dışında metin içerisinde geçen, tekrarlar, asonans ve aliterasyon gibi ses olayları, vezin ve kafiyelerle birlikte bu görevi üstlenir.

Şairin dil ve üslubunu orijinalleştiren önemli unsurlar vardır. Bunlar: Deyim, atasözü ve ikilemelerin neredeyse her şiirde anlatımı güçlendirici payandalar olarak kullanılmasıdır. Bunların yanında vurgunun sağlandığı tekrarlar manzumelere ayrı bir güzellik ve akıcılık kazandırır. Şairin önemli bir yönü de halk ağzı deyiş ve kelimelere çokça yer vermesidir. Edebî sanatlara şiirlerinde yer veren şair, özellikle tezat, benzetme, teşhis sanatını metinlerin ana öğesi hâline getirir. İstiare, mecaz-ı mürsel, nida, tekrir, tenasüp, tecahül-i ârif, istifham ve telmih diğer kullanılan edebî sanat türleridir. Şair, yüzyllardır süregelen geleneğin takipçilerinden biridir. O, kendinden önceki sanatkârların kullandığı her kelime ve ibarelerden faydalanmış, bunlar vasıtasıyla kendisine özgü bir hiciv üslubu ve şiiri ortaya koymaya muvaffak olmuştur. O, aynı zaman da Türk şiirini bir bütün halinde içselleştirmiş, Divan,

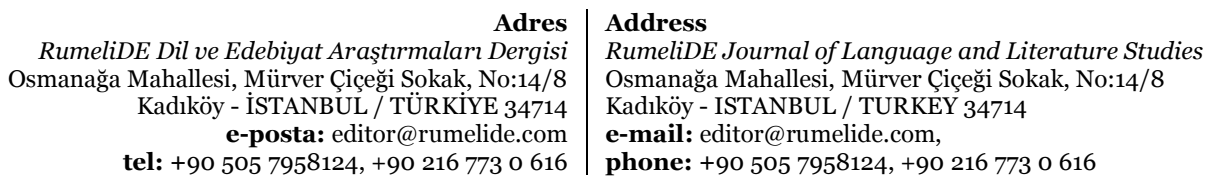


Halk ve Yeni Türk şiirine ait unsurları eserlerinde ziyadesiyle kullanmış, tam bir gelenekçi şairdir. Hülasa, Namdar Rahmi Karatay, 1933-1950 yılları arasında Cumhuriyet Dönemi Türk Edebiyatı hiciv şiirinin en önemli kilometre taşlarından biridir.

\section{Kaynakça}

Aksan, D. (1996), Türkçenin Söz Varhı̆̆ı, Ankara: Engin.

Arabacı, C. (1991), Millî Mücâdele Dönemi Konya Öğretmenleri, Konya: Damla Matbaacılık.

Arısoy, M. S.(1985), Türk Halk Şiiri Antolojisi, Ankara: Bilgi.

Birinci, A. (2012a), "Namdar Rahmi Karatay’ın Hikâyesi”, Türk Yurdu, Ağustos, 32 (300), 30-35.

Birinci, A. (2012b), “Namdar Rahmi Karatay’ın Hikâyesi”, Türk Yurdu, Eylül, 32 (301), 40-46.

Boynukara, H. (1997), Modern Eleştiri Terimleri, İstanbul: Boğaziçi.

Çandır, K. (2019a), "Namdar Rahmi Karatay'dan Tahsin Nâhid Uygur'a Gönderilen "Yıllık Destan" İsimli Siir Üzerinde Bir İnceleme", Uluslararası Multidisipliner Sosyal Bilimler Kongresi Bildiri Özetler Kitabı içinde (s.205-206), 07-10 Mayıs 2019 Dil ve Tarih Coğrafya Fakültesi, Ankara/Türkiye. Prof. Dr. Salih Çeçen, Zeynel Karacagil (Ed.), Ankara: Bilgin Kültür Sanat.

Çandır, K. (2019b), "Namdar Rahmi Karatay'dan Tahsin Nâhid Uygur'a Gönderilen "Ylllık Destan" İsimli Şiir Üzerinde Bir İnceleme”, Sosyal Bilimler İnsan Çalsşmaları 2, Eğitim Bilimleri, Dil Bilimleri ve Felsefe Üzerine Güncel Tartışmalar içinde (s.16-31). Zeynel Karacagil, Ali Osman Tiro (Ed.), Ankara: Bilgin Kültür Sanat.

Dilçin, C. (1992), Örneklerle Türk Şiir Bilgisi, (2. Baskı), Ankara: Türk Dil Kurumu.

Eşekarısı "1934", “Geçti Bor'un Pazarı”, Akbaba, 8 Şubat, (6), 6.

Eşekarısı “1937", "Hayat Pokeri”, Akbaba, 12 Mart, (166), 7.

Eşekarısı “1940”, “Karaman’ın Koyunu”, Akbaba, 28 Mart, (323), 5.

Karamanın Koyunu Efsanesi, 18 Şubat 2012 tarihinde https://kulturportali.gov.tr/turkiye/karaman/kulturatlasi/karamanin-koyunu-sonra-cikaroyunu-efsanes adresinden erișildi.

Karataş, T. (2007), Ansiklopedik Edebiyat Terimleri Sözlüğü, Ankara: Akçağ.

Karatay, N. R. (1932), Felsefi Meslekler Vokabüleri, Afyon: Doğan Matbaası.

Karatay, N. R. (1941), Namık Kemal ve İdealizmi, Bursa: Bursa Vilâyet Matbaası.

Karatay, N. R. (1943), “Bir Oluş Hikâyesi”, Gerçek Yolu, Şubat, Sayı: (1), 7-8, 31.

Karatay, N. R. (1945), Yazma Dersleri, İstanbul: Maarif Matbaası.

Karatay, N. R. (1952a), Geçti Bor’un Pazarı, İstanbul: Yenilik Matbaası.

Karatay, N. R. (1952b), Kitaplarmmn Hikâyesi, İstanbul: Berksoy.

Karatay, N. R. (1952c), Paris Mektuplart, İstanbul: Berksoy.

Karatay, N. R. (1954), Geçti Bor’un Pazart: Şiirler, Ankara: Yeni Matbaa.

Karatay, N. R. (2004), Leyleğin Ömrü,-Geçti Bor’un Pazart-, İstanbul: Yaba.

Karatay, N. R. (2018), Felsefi Meslekler Vokabüleri, (Yay. Haz.) Recep Alpyağıll, İstanbul: İz.

Muşta, M. G. (1990), Konya Enerjetizm Felsefe Okulu, Ankara: Kültür Bakanlığı.

Okay, O. (1998), "Hiciv", TDV İslâm Ansiklopedisi (DİA) içinde (c.17, ss.452-454). İstanbul: Türkiye Diyânet Vakfi.

Olgun, T. (1936), Edebiyat Lügati, İstanbul: Âsâr-ı İlmiye Kütüphanesi Neşriyâtı.

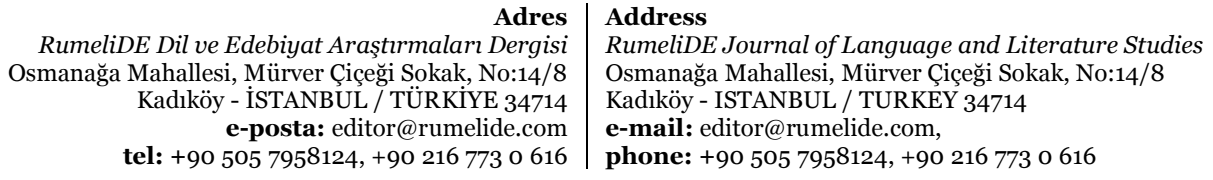


Öksüz, M. (2015), Cumhuriyet Devri Türk Şiirinde Hiciv (1923-1960). Yayımlanmamış doktora tezi, Selçuk Üniversitesi, Konya.

Öngören, F. (1983), Cumhuriyet Dönemi Türk Mizahı ve Hicvi, Ankara: Türkiye İş Bankası Kültür.

Pala, İ. (1998), "Hezl”, TDV İslâm Ansiklopedisi (DİA) içinde (c. 17, ss. 305-306). İstanbul: Türkiye Diyânet Vakfi.

Recaî-zade M. Ekrem (1997), Bütün Eserleri II, (Haz.) İsmail Parlatır-Nurullah Çetin, Hakan Sazyek, İstanbul: Milli Eğitim Bakanlığı.

Şeyhî (2011), Harnâme, (Haz.) Mehmet Özdemir, İstanbul, Kapı.

Tonga, N. (2020), "Kederli Bir Hayatın Muhâsebesi: Namdar Rahmi Karatay ve Poker Destanı", Kumar Kitabı, Emine Gürsoy Naskali (Ed.), İstanbul: Kitabevi.

Yağma Hasan’ın Böreği Deyimi, 18 Mart 2021 tarihinde (https://www.egitimsistem.com/yagmahasanin-boregi-deyiminin-anlami-ve-kisaca-hikayesi-46725h.htm) adresinden erişildi. 